\title{
Climate change in Sri Lanka: myth or reality? Evidence from long-term meteorological data
}

\author{
W.A.J.M. De Costa \\ Department of Crop Science, Faculty of Agriculture, University of Peradeniya, Peradeniya.
}

Submitted: 09 April 2008

\begin{abstract}
Climate change is one of the most-discussed issues in current global fora. The objective of this paper is to seek evidence for climate change in Sri Lanka by analyzing longterm (i.e. from 1869 to 2007) monthly data of air temperature and rainfall from seven selected locations (i.e. Anuradhapura, Kurunegala, Kandy, Ratnapura, Badulla, Nuwara Eliya and Colombo) representing the major climatic zones of the country. Decadal mean air temperatures of all selected locations, except Kandy, showed highly significant $(p<0.001)$ linear increasing trends over the entire 140 -year period considered. In all locations, including Kandy, almost continuous decadal warming has occurred during the last 6-10 decades. The rates of continuous warming in all locations except Ratnapura exceeded, by a substantial margin, the global mean (i.e. 0.074 ${ }^{\circ} \mathrm{C}$ decade $^{-1}$ ) during the period from 1906 to 2005. Analysis of frequency distributions of annual mean air temperatures showed that the above increases have occurred because of a shift in the entire distribution of temperatures over time rather than due to a few extremely warm years. Four out of the seven locations (i.e. Anuradhapura, Kandy, Badulla and Nuwara Eliya) examined showed statistically significant $(\mathrm{p}<0.05)$ linear declining trends of decadal mean annual rainfall $\left(\mathrm{RF}_{\mathrm{a}}\right)$ with time over the whole 140-year period. The highest rate of rainfall decline was shown in Nuwara Eliya at $52 \mathrm{~mm} \mathrm{decade}^{-1}$. Within the respective trends over the 140 -year period, a period of significant $(\mathrm{p}<0.05)$ decline of decadal mean $\mathrm{RF}_{\mathrm{a}}$ could be identified in all locations except Colombo. In particular, Kurunegala has shown a rainfall decline of $121 \mathrm{~mm} \mathrm{decade}^{-1}$ from the 1970s onwards. Kandy and Nuwara Eliya have also shown rainfall declines in the range of $64-67 \mathrm{~mm} \mathrm{decade}^{-1}$ since 1940 s and 1920 s respectively. In all locations, mean $\mathrm{RF}_{\mathrm{a}}$ during the period from 1990 to 2007 was lower than that during the 1950-1989 period. The reductions ranged from $28 \mathrm{~mm} \mathrm{yr}^{-1}$ at Ratnapura to $202 \mathrm{~mm} \mathrm{yr}^{-1}$ at Kurunegala. Analysis of shifts in rainfall distributions show that rainfall reductions in the years of extremely lower and higher rainfall have contributed relatively more to the mean rainfall reductions in successive periods than rainfall reductions in the years of average rainfall. In all locations, $\mathrm{RF}_{\mathrm{a}}$ showed decreasing trends, of varying
\end{abstract}

strengths, with increasing mean annual temperature, $T_{a}$, with Nuwara Eliya showing the highest rate of rainfall decline (371 $\left.\mathrm{mm}{ }^{\circ} \mathrm{C}^{-1}\right)$. Analysis of monthly and annual rainfall data from 1950 to 1989 showed that the El Niño phenomenon reduced $\mathrm{RF}_{\mathrm{a}}$ during the following year in all locations, mainly because of rainfall reductions in June-July (South-West Monsoon) and January-February. From 1990 onwards, these post-El Niño $\mathrm{RF}_{\mathrm{a}}$ reductions have increased in all locations except Colombo and Ratnapura, where post-El Niño $\mathrm{RF}_{\mathrm{a}}$ has been higher than in normal years. Notably, in all locations, post-El Niño reductions of June-July rainfall have been absent since 1990, where RF reductions have occurred because of reductions in JanuaryFebruary and October-December (North-East Monsoon) rainfall.

Keywords: El Niño, monsoon, rainfall, temperature, warming

\section{INTRODUCTION}

Climate change is one of the most discussed issues in global fora today. It has been identified as a major threat to natural and man-made ecosystems and human civilization in the $21^{\text {st }}$ century and thereafter. Although different parts of the world are predicted to be affected by climate change to varying degrees, many of the drivers and effects of climate change are global. No particular region or country, including Sri Lanka, is immune to climate change. Therefore, it is imperative that the magnitude of climate change in Sri Lanka and its impacts are identified and quantified. While this is a vast and complex area to tackle, there has been little analytical or experimental work carried out in Sri Lanka. In fact, there is even some skepticism in certain quarters, as has been the case globally as well, whether climate change is a myth or reality ${ }^{1,2}$. Is it really happening or is it just a misguided misconception propagated by a group of scientists and environmental activists and other parties 
with vested interests? Do the long-term meteorological data adequately support the case for systematic and consistent climate change or is it a flawed interpretation of relatively short-term data while ignoring the longterm cyclic trends?

Therefore, the primary objective of this paper is to examine long-term climatic data from different climatic zones of Sri Lanka to see whether they support a claim for long-term climate change. If the data do in fact show that long-term climate change has occurred, quantification of its magnitude becomes an essential first step in devising appropriate adaptation and mitigation measures. Hence, estimating the magnitude and rate of climate change in terms of two key climatic variables, namely air temperature and rainfall, is an implicit secondary objective of this work. Although Sri Lanka may be occupying a unique position owing to its geographical location, it cannot escape the drivers of global climate change and their impacts. Therefore, this paper will first discuss the global scenario of climate change and its drivers, and then discuss the specific case for Sri Lanka.

\section{Climate change : the global case and projected scenarios}

\section{Definitions}

Climate is the totality of above-ground environmental factors and its long-term variation. Variation in time (and space) is inherent in the climate. Therefore, to conclude that the climate has changed, a discernible shift in the long-term variation pattern of climate variability has to be shown. In the past two years, there have been two comprehensive reports on global climate change and its impacts, the Fourth Assessment Report (AR4) ${ }^{3}$ of the Intergovernmental Panel on Climate Change (IPCC) published in 2007 and the Stern Review ${ }^{4}$ published in 2006. Both reports conclude that there is strong evidence for long-term climate change, and that there is a strong human influence driving this climate change. Statistically significant variations in the mean state of the climate or of its variability, typically persisting for decades or longer, are defined as climate change ${ }^{3,5}$.

\section{Temperature}

Climate change is usually quantified in terms of easily measurable variables such as air temperature and precipitation. Sustained long-term increase in global mean surface temperature, $T_{a}$ (i.e. the average of near surface air temperature over land, and sea surface temperature), popularly termed 'global warming', is the most widelyused parameter of climate change. The Third Assessment Report (TAR) of the IPCC ${ }^{5}$ estimated that the measured $\mathrm{T}_{\mathrm{a}}$ increased by $0.6( \pm 0.2)^{\circ} \mathrm{C}$ during the 140 years up to 2000 . The 100 -year linear trend of $0.74( \pm 0.18)^{\circ} \mathrm{C}$ from 1906 to 2005 given in the Fourth Assessment Report ${ }^{3}$ showed a greater rate of warming than that given in the TAR. This was owing to 11 of the 12 years from 1995 to 2006 being among the 12 warmest years since air temperature measurements began in 1850 . The AR4 further estimates that the $0.13( \pm 0.3)^{\circ} \mathrm{C}$ per decade rate of warming during the 50 -year period from 1956 to 2005 , was nearly twice that during the 100 -year period from 1906 to 2005 . There is strong evidence that the warming that occurred during the $20^{\text {th }}$ century, especially during its second half, was unprecedented even on a longer time scale such as the millennium between years 1000 and $2000^{5}$. However, an interesting finding of AR4 has been that the difference between day and night temperatures (i.e. the diurnal temperature range, DTR) has not changed during the period from 1979 to 2004, implying that both temperatures have increased in equal proportions. This was in contrast to the finding, based on data from 1950 to 1993 , in the TAR that DTR had decreased.

\section{Precipitation}

Increases in the near-surface air temperature and sea surface temperature trigger a series of processes leading to changes in precipitation patterns. The TAR identifies long-term variations in precipitation over different latitudinal ranges during the $20^{\text {th }}$ century. Decadal increases were identified in the tropical- $(0.2-0.3 \%$ per decade), mid- and high latitudes (0.5-1.0\% per decade) while decreases $(0.3 \%$ per decade $)$ were identified in the sub-tropical $\left(10^{\circ} \mathrm{N}\right.$ to $\left.30^{\circ} \mathrm{N}\right)$ latitudes. There has also been a clear increase in the proportion of precipitation being received in heavy precipitation events. Conversely, this also means that the frequency of 'dry' or low rainfall periods has increased. The AR4 reports an increase in the frequency, length and intensity of droughts since 1970 over wider areas, especially in tropics and sub-tropics ${ }^{3}$.

Warmer temperatures have increased evaporation rates so that the atmospheric humidity levels have increased. It is likely that higher water vapour concentrations in the atmosphere have caused heavy precipitation events and increased tropical cyclone activity. The higher evaporation rates have also increased the incidence of salinity in the lower latitudes ${ }^{3}$. 


\section{Sea level rise}

The warming since 1900 has been slower in oceans than over land surfaces ${ }^{3}$. Since 1961, oceans have absorbed $80 \%$ of the extra heat energy retained by the earth-atmosphere system thus causing the sea level to rise because of thermal expansion. In addition, melting of polar ice, glaciers and snow caps under warmer temperatures contributes to sea level rise. The global sea level rise of $3.1( \pm 0.7) \mathrm{mm}$ per year during 1993-2003 was higher than the corresponding rate of $1.8( \pm 0.5) \mathrm{mm}$ per year during 1961-2003.

\section{Radiation receipt}

Measurements in different parts of the world have shown a reduction in global irradiance. This has been attributed to increased amounts of aerosols (i.e. sulphur dioxide, soot and dust) in the atmosphere which increases the reflection of incoming solar radiation away from the earth's surface and back into space. Greater amounts of aerosols in the atmosphere causes the formation of clouds with a greater number of smaller water droplets as compared to the clouds formed in an atmosphere with fewer aerosols. Clouds with a greater number of smaller droplets reflect a greater proportion of incoming radiation, thus leading to a reduction of global irradiance. This phenomenon is termed 'global dimming'. During the three decades from 1960 to 1990, the reduction of global irradiance is estimated to be about $4 \%{ }^{6,7}$. However, because of the various steps that have been taken, especially in Europe and North America, to reduce the emission of aerosols into the atmosphere, the trend of global dimming has reversed since the $1990 \mathrm{~s}^{8-10}$.

\section{Drivers of global climate change}

There is strong evidence that human activities leading to increased greenhouse gas (GHG) concentrations in the atmosphere are the principal cause of long-term climate change, and particularly the observed warming in the last 50 years $^{3,5}$. There is less than $5 \%$ probability that the observed changes in climate are due to natural climatic variation $^{3}$.

Carbon dioxide $\left(\mathrm{CO}_{2}\right)$, methane $\left(\mathrm{CH}_{4}\right)$, nitrous oxide $\left(\mathrm{N}_{2} \mathrm{O}\right)$ and several halocarbons (a group of gases containing chlorine, fluorine and bromine) are the major GHGs that cause global warming by retaining part of out-going thermal radiation from the earth's surface. Atmospheric concentrations of all these GHGs have increased significantly since the beginning of industrial revolution around 1750 . There has been a $70 \%$ increase of atmospheric GHGs during the period from 1970 to
20043. Specifically, the annual emission of $\mathrm{CO}_{2}$, which is the most important GHG, has increased by $80 \%$ during the above period. Furthermore, during the ten year period from 1995 to 2004, the rate of emission of GHGs (0.92 $\mathrm{Gt}_{\mathrm{CO}_{2}}$-eq per year) was greater than the corresponding rate between 1970 and 1994 (0.43 $\mathrm{Gt} \mathrm{CO}_{2}$-eq per year). The atmospheric $\mathrm{CO}_{2}$ concentration $\left(\mathrm{C}_{\mathrm{a}}\right)$ of $379 \mathrm{ppm}$ in 2005 had exceeded, by far, its natural variation range of $180-300 \mathrm{ppm}$ during the last 650,000 years. The annual rate of increase of $\mathrm{C}_{\mathrm{a}}$ during the decade from 1995 to 2005 (i.e. $1.9 \mathrm{ppm}$ per year) was greater than the average of 1.4 ppm per year from 1960 to 2005 .

The largest growth in GHG emissions during the period 1970-2004 has come from energy, transport and industrial sectors, while the emissions from deforestation and agriculture have grown at a lower rate. During the above period, the global population growth $(69 \%)$ and the global income growth $(77 \%)$, which are two strong drivers of $\mathrm{CO}_{2}$ emissions, outweighed the $33 \%$ reduction in global energy intensity (i.e. $\mathrm{CO}_{2}$ emission per unit of energy generated). South Asia's share of the per capita global GHG emissions is $13.1 \%$ in comparison to USA \& Canada's $19.4 \%$. Per capita GHG emissions are the lowest in South Asia ( $\sim 3 \mathrm{t} \mathrm{CO}_{2}$ equivalents per capita) as compared to other regions of the world (e.g. $\sim 26 \mathrm{t} \mathrm{CO}_{2}-$ eq per cap.). However, because of its greater population and lower GDP, South Asia has a higher GHG emission level per unit GDP ( $\sim 0.9 \mathrm{t} \mathrm{CO}_{2}$-eq per US\$) than USA \& Canada $\left(\sim 0.7 \mathrm{t} \mathrm{CO}_{2} \text {-eq per US\$) }\right)^{3}$.

In $\mathrm{AR}^{3}$, the combined anthropogenic radiative forcing (i.e. the amount by which the earth's radiation balance changes due to changes in atmospheric composition) since 1750 was estimated to be $+1.6 \pm 1.0$ $\mathrm{Wm}^{-2}$. Full details of the different sources of positive and negative radiation forcing and atmospheric feedbacks are given in AR4 ${ }^{3}$.

\section{Projected scenarios of global climate change}

Predictions of climate change depend on the different alternative pathways of development and their projected GHG emissions ${ }^{11}$. All these scenarios project a $25-90 \%$ increase of GHG emissions between 2000 and $2030^{3}$. Fossil fuels are expected to continue to be the dominant source of energy so that $\mathrm{CO}_{2}$ emissions are predicted to increase by $40-110 \%$. Consequently, AR 4 projects the global mean temperature to increase at a rate of $0.2^{\circ} \mathrm{C}$ per decade during the next two decades. Thereafter, the warming projections depend increasingly on specific development and emission scenarios (Table 1). Overall, the projected warming by the end of $21^{\text {st }}$ century ranges from 1.1 to $6.4^{\circ} \mathrm{C}$. This is broadly consistent with the 
Table 1: Projected global average surface warming and sea level rise at the end of the $21^{\text {st }}$ century.

\begin{tabular}{|c|c|c|c|}
\hline \multirow[b]{2}{*}{ Case $\dagger$} & \multicolumn{2}{|c|}{$\begin{array}{c}\text { Temperature change } \\
\left({ }^{\circ} \mathrm{C} \text { at } 2090-2099 \text { relative to }\right. \\
1980-1999) \$\end{array}$} & \multirow{2}{*}{$\begin{array}{c}\text { Sea level rise } \\
\text { (m at 2090-2099 relative to } \\
\text { 1980-1999) } \\
\text { Model-based range } \\
\text { excluding future rapid dynamic } \\
\text { changes in ice flow }\end{array}$} \\
\hline & $\begin{array}{c}\text { Best } \\
\text { estimate }\end{array}$ & $\begin{array}{c}\text { Likely } \\
\text { range }\end{array}$ & \\
\hline \multicolumn{4}{|l|}{ Constant year 2000} \\
\hline GHG concentrations & 0.6 & $0.3-0.9$ & Not available \\
\hline B1 scenario & 1.8 & $1.1-2.9$ & $0.18-0.38$ \\
\hline A1T scenario & 2.4 & $1.4-3.8$ & $0.20-0.45$ \\
\hline B2 scenario & 2.4 & $1.4-3.8$ & $0.20-0.43$ \\
\hline A1B scenario & 2.8 & $1.7-4.4$ & $0.21-0.48$ \\
\hline A2 scenario & 3.4 & $2.0-5.4$ & $0.23-0.51$ \\
\hline A1FI scenario & 4.0 & $2.4-6.4$ & $0.26-0.50$ \\
\hline
\end{tabular}

Note: $\uparrow A 1$ - Rapid economic growth, with convergence between different regions of the world. A1FI - Economic growth with high dependence on fossil energy sources; A1T - Economic growth with non-fossil energy sources; A1B - Economic growth with a balanced mixture of energy sources; A2 - Regionally-oriented and unevenly-distributed (i.e. divergent) economic growth, which is slower than in A1; B1 - Convergent world which is rapidly moving towards global solutions to economic, social and environmental sustainability with the introduction of clean and resource-efficient technologies; B2 - Intermediate rates of economic development focusing on environmental protection and social equity, but with emphasis on local solutions and less rapid and more diverse technological change than in $\mathrm{B} 1$ and A1. Approximate $\mathrm{CO}_{2}$-equivalent GHG concentrations corresponding to the B1, AIT, B2, A1B, A2 and A1FI scenarios are about 600,700, 800, 850, 1250 and $1550 \mathrm{ppm}$, respectively. These scenarios are considered to be marker scenarios in the Special Report on Emissions Scenarios (SRES) of the IPCC ${ }^{11}$. $\ddagger$ Temperature changes are expressed as the difference from the period 1980-1999. To express the change relative to the period $1850-1899$ add $0.5^{\circ} \mathrm{C}$.

(Source: IPCC, 2007b ${ }^{12}$ ).
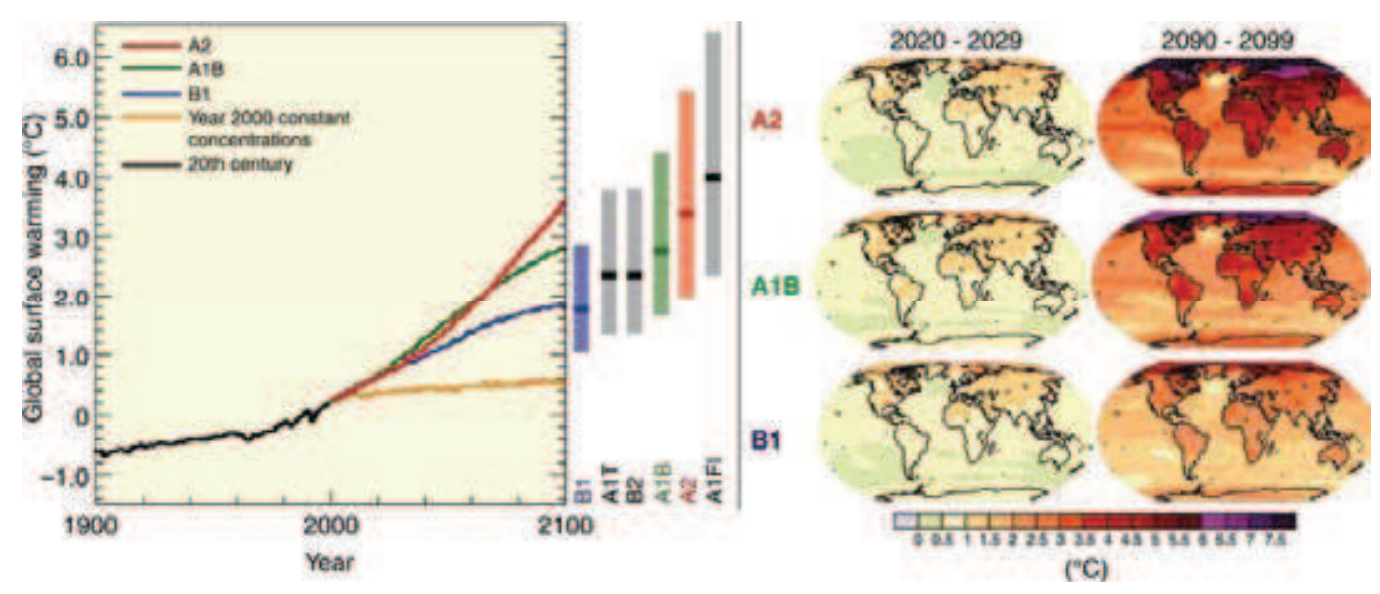

Figure 1: Left panel: Solid lines are multi-model global averages of surface warming (relative to 1980-1999) for the SRES scenarios A2, A1B and B1, shown as continuations of the 20th century simulations. The orange line is for the experiment where concentrations were held constant at year 2000 values. The bars in the middle of the figure indicate the best estimate (solid line within each bar) and the likely range assessed for the six SRES marker scenarios at 2090-2099 relative to 1980-1999. The assessment of the best estimate and likely ranges in the bars includes the Atmosphere-Ocean General Circulation Models (AOGCMs) in the left part of the figure, as well as results from a hierarchy of independent models and observational constraints. Right panels: Projected surface temperature changes for the early and late $21^{\text {st }}$ century relative to the period 1980-1999. The panels show the multi-AOGCM average projections for the A2 (top), A1B (middle) and B1 (bottom) SRES scenarios averaged over decades 2020-2029 (left) and 2090-2099 (right).

(Source: IPCC, 2007b ${ }^{12}$ ). 


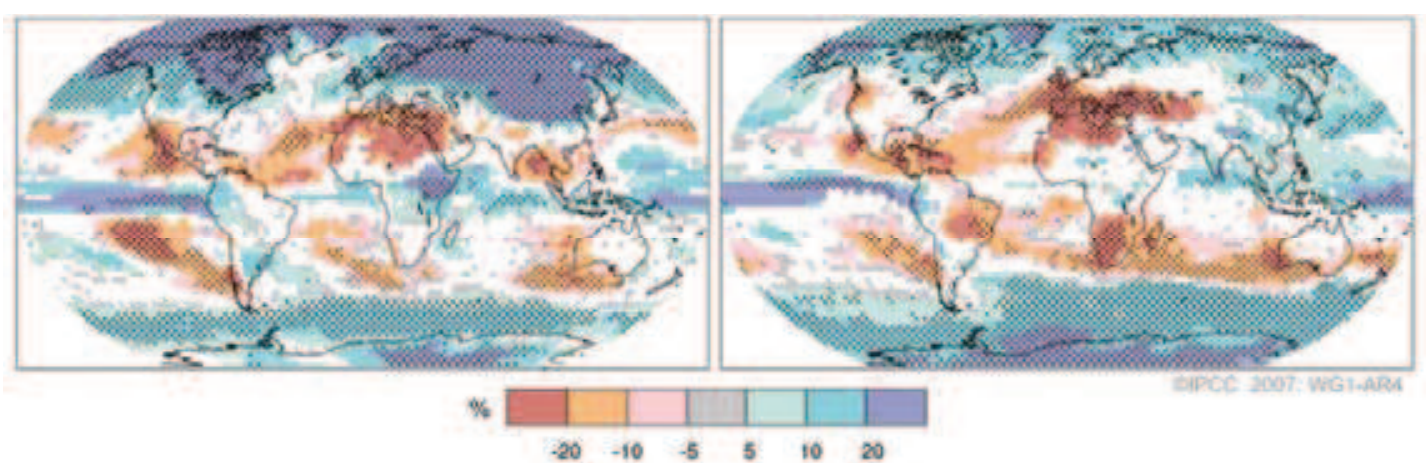

Figure 2: Relative changes in precipitation (in percent) for the period 2090-2099, relative to 1980-1999. Values are multi-model averages based on the SRES A1B scenario for December to February (left) and June to August (right). White areas are where less than $66 \%$ of the models agree on the sign of the change and stippled areas are where more than $90 \%$ of the models agree on the sign of the change.

(Source: IPCC, 2007b ${ }^{12}$ ).

range of 1.4 to $5.8^{\circ} \mathrm{C}$ predicted by the TAR ${ }^{5}$. AR4 also projects scenario-independent geographical patterns of warming with the greatest warming expected in the Northern high latitudes and the least in the Southern Ocean near Antarctica and Northern Atlantic. Warming in the tropical zone is projected to be intermediate ${ }^{12}$ (Figure 1). Frequencies of warm spells and heat waves and heavy precipitation events are also predicted to increase. The AR4 predicts a sea level rise range of $18-59 \mathrm{~cm}$ by 2090-2099. Increased sea surface temperatures are likely to cause more intense tropical cyclones and higher peak wind speeds and heavier precipitation events.

The AR4 makes predictions about possible changes in precipitation patterns with a greater degree of certainty than the TAR. Precipitation increases as much as $20 \%$ are highly likely in the Northern latitudes while decreases as much as $20 \%$ are likely in some of the sub-tropical regions. Importantly, there is increasing evidence that the annual rainfall will come in a fewer, more intense rainfall events ${ }^{13,14}$. Since the mid-1970s, there have been rainfall decreases over some tropical regions, with tropical Asia recording a marginal decrease while tropical North Africa showing a 3-4\% decrease ${ }^{15,16}$ and Amazonia showing no significant variation ${ }^{15}$. On a global scale, the percentage of land area under moderate drought at a given time is expected to increase from the current level of $25 \%$ to $50 \%$ while the corresponding percentage for extreme drought is projected to increase from $3 \%$ to $30 \%{ }^{17}$.

Most of the climatic models predict precipitation increases in the tropical zone ${ }^{12}$ (Figure 2). The area around Sri Lanka is projected to receive a $10-20 \%$ increase in precipitation during June - August period. However, Sri Lanka is located very close to an area where up to a $10 \%$ decrease in December - February precipitation is predicted. This could have important implications for Sri Lankan Agriculture sector because the above period coincides with the latter half of the North-East monsoon, which brings rainfall to the whole country including its major agricultural area, the dry zone.

The Stern Review ${ }^{4}$ predicts a doubling of atmospheric GHGs by 2030 - 2060, causing a global warming of $2-5^{\circ} \mathrm{C}$. It also cites new studies which suggest a $20 \%$ probability of the warming being greater than $5^{\circ} \mathrm{C}$. If $\mathrm{GHG}$ emissions remain at the current levels, their concentrations could be three times greater than pre-industrial levels by 2100 , leading to a warming of $3-10^{\circ} \mathrm{C}^{4,18}$.

\section{Climate change : the local case}

\section{Evidence for long-term change in key climatic parameters}

In comparison to most countries in the developing world, Sri Lanka has been collecting the basic meteorological data over a long time period through a network of stations. This data base can be used to examine evidence for climate change in Sri Lanka. The present paper analyzes long-term data ${ }^{19}$ from seven selected locations representing different agroecological zones of Sri Lanka (Table 2).

As air temperature is a primary indicator of climate change, annual and monthly mean air temperatures were subjected to this analysis of evidence for climate change in Sri Lanka. Because of the importance of water for human consumption, agriculture, industries and other activities, long-term annual and monthly rainfall data were also analyzed. 
Table 2: Locations selected for the analysis of long-term air temperature and rainfall data ${ }^{19}$.

\begin{tabular}{lcclc}
\hline Location & Latitude and longitude & Altitude $(\mathrm{m})$ & Agroecological zone & $\begin{array}{c}\text { Time period } \\
\text { considered }\end{array}$ \\
\hline Anuradhapura & $8.3015^{\circ} \mathrm{N}, 80.4279^{\circ} \mathrm{E}$ & 89 & Low-Country Dry Zone & $1870-2007$ \\
Kurunegala & $7.4667^{\circ} \mathrm{N}, 80.3667^{\circ} \mathrm{E}$ & 116 & Low-Country Intermediate Zone & $1885-2007$ \\
Kandy & $7.3333^{\circ} \mathrm{N}, 80.6333^{\circ} \mathrm{E}$ & 477 & Mid-Country Wet Zone & $1870-2007$ \\
Ratnapura & $6.6833^{\circ} \mathrm{N}, 80.4000^{\circ} \mathrm{E}$ & 33 & Low-Country Wet Zone & $1869-2007$ \\
Badulla & $6.9833^{\circ} \mathrm{N}, 81.0500^{\circ} \mathrm{E}$ & 670 & Up-Country Intermediate Zone & $1869-2007$ \\
Nuwara Eliya & $6.9667^{\circ} \mathrm{N}, 80.7667^{\circ} \mathrm{E}$ & 1895 & Up-Country Wet Zone & $1869-2007$ \\
Colombo & $6.8222^{\circ} \mathrm{N}, 79.8862^{\circ} \mathrm{E}$ & 7 & Low-Country Wet Zone & $1869-2007$ \\
\hline
\end{tabular}

\section{Long-term variation of annual air temperature $(T)$}

As expected, annual mean $\mathrm{T}_{\mathrm{a}}$ (i.e. mean of mean monthly air temperatures) showed considerable year-to-year variation at all locations examined (Figure 3). However, all locations except Kandy showed an increasing trend in annual mean $\mathrm{T}_{\mathrm{a}}$ over the nearly 140 -year period examined. The year-to-year variation could be minimized by computing the decadal mean air temperatures, which also showed a similar increasing trend over time. All locations except Kandy showed significant positive linear regressions of decadal mean $\mathrm{T}_{\mathrm{a}} \mathrm{s}$ against time, with $\mathrm{R}^{2}$ values ranging from 0.93 to 0.30 . It is particularly notable that the rates of warming at three locations (i.e. Nuwara Eliya, Badulla and Anuradhapura) were greater than the global average rate of $0.0074^{\circ} \mathrm{C} \mathrm{yr}^{-1}$ given in IPCC AR4 ${ }^{3}$ for the period between 1906 and 2005. Nuwara Eliya showed the highest rate of warming, with the decadal mean $\mathrm{T}_{\mathrm{a}}$ showing an almost continuous increase throughout the whole period (Figure 3f). All locations, there was a relative warming period during the last 2-3 decades of the $19^{\text {th }}$ century. At all locations except Kandy (Figure 3c) and Nuwara Eliya (Figure 3f) this was followed by a cooling period during the first 1-2 decades of the $20^{\text {th }}$ century. Thereafter, decadal mean $\mathrm{T}_{\mathrm{a}} \mathrm{s}$ of all locations, including Kandy, showed almost continuous increases. At Ratnapura, this period of almost continuous decadal warming started from the second decade of the $20^{\text {th }}$ century (Figure 3d), whereas at Kandy it started from 1950s (Figure 3c). In the rest of the locations, this period of warming started in the $1930 \mathrm{~s}$. In all locations, including Nuwara Eliya, the respective rates of almost continuous warming were greater than the overall rate of warming during the total period considered (i.e. 1869 to 2007) (Table 3). Furthermore, the rates of continuous warming at all locations except Ratnapura exceeded, by a substantial margin, the global mean rate of warming (i.e. $0.074{ }^{\circ} \mathrm{C}$ decade $^{-1}$ ) during the period from 1906 to 2005 (IPCC, 2007). Even the rate of continuous warming at Ratnapura was close to the global mean. The long-term air temperature regime of Kandy differed from that of other locations by a significant decadal warming period from 1900 up to 1950 at a rate of $0.147( \pm 0.021){ }^{\circ} \mathrm{C}$ decade $^{-1}\left(\mathrm{R}^{2}=0.94\right)$. Anuradhapura also had experienced a significant and continuous decadal warming of 0.174

Table 3: Rates of increase of decadal mean air temperatures during the total period considered and during the period of almost continuous warming, for selected locations in Sri Lanka

\begin{tabular}{|c|c|c|c|c|c|}
\hline & \multicolumn{2}{|c|}{ Total period (1869-2007) } & \multicolumn{3}{|c|}{ Period of almost continuous warming } \\
\hline & 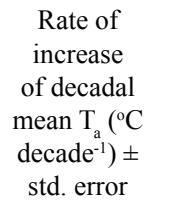 & $\begin{array}{l}\mathrm{R}^{2} \text { value } \\
\text { of linear } \\
\text { regression }\end{array}$ & 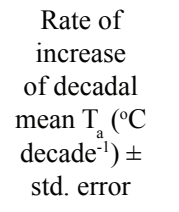 & $\begin{array}{l}\mathrm{R}^{2} \text { value } \\
\text { of linear } \\
\text { regression }\end{array}$ & Period \\
\hline Anuradhapura & $0.078 \pm 0.019$ & 0.58 & $0.195 \pm 0.021$ & 0.94 & 1930-2007 \\
\hline Kurunegala & $0.053 \pm 0.012$ & 0.63 & $0.104 \pm 0.015$ & 0.89 & $1930-2007$ \\
\hline Kandy & n.s. & - & $0.096 \pm 0.019$ & 0.86 & $1950-2007$ \\
\hline Ratnapura & $0.049 \pm 0.015$ & 0.47 & $0.065 \pm 0.013$ & 0.75 & 1910-2007 \\
\hline Badulla & $0.086 \pm 0.018$ & 0.66 & $0.191 \pm 0.021$ & 0.94 & $1930-2007$ \\
\hline Nuwara Eliya & $0.106 \pm 0.008$ & 0.93 & $0.141 \pm 0.014$ & 0.94 & $1930-2007$ \\
\hline Colombo & $0.040 \pm 0.018$ & 0.30 & $0.154 \pm 0.018$ & 0.93 & $1930-2007$ \\
\hline
\end{tabular}

Note: n.s. - No significant linear relationship 

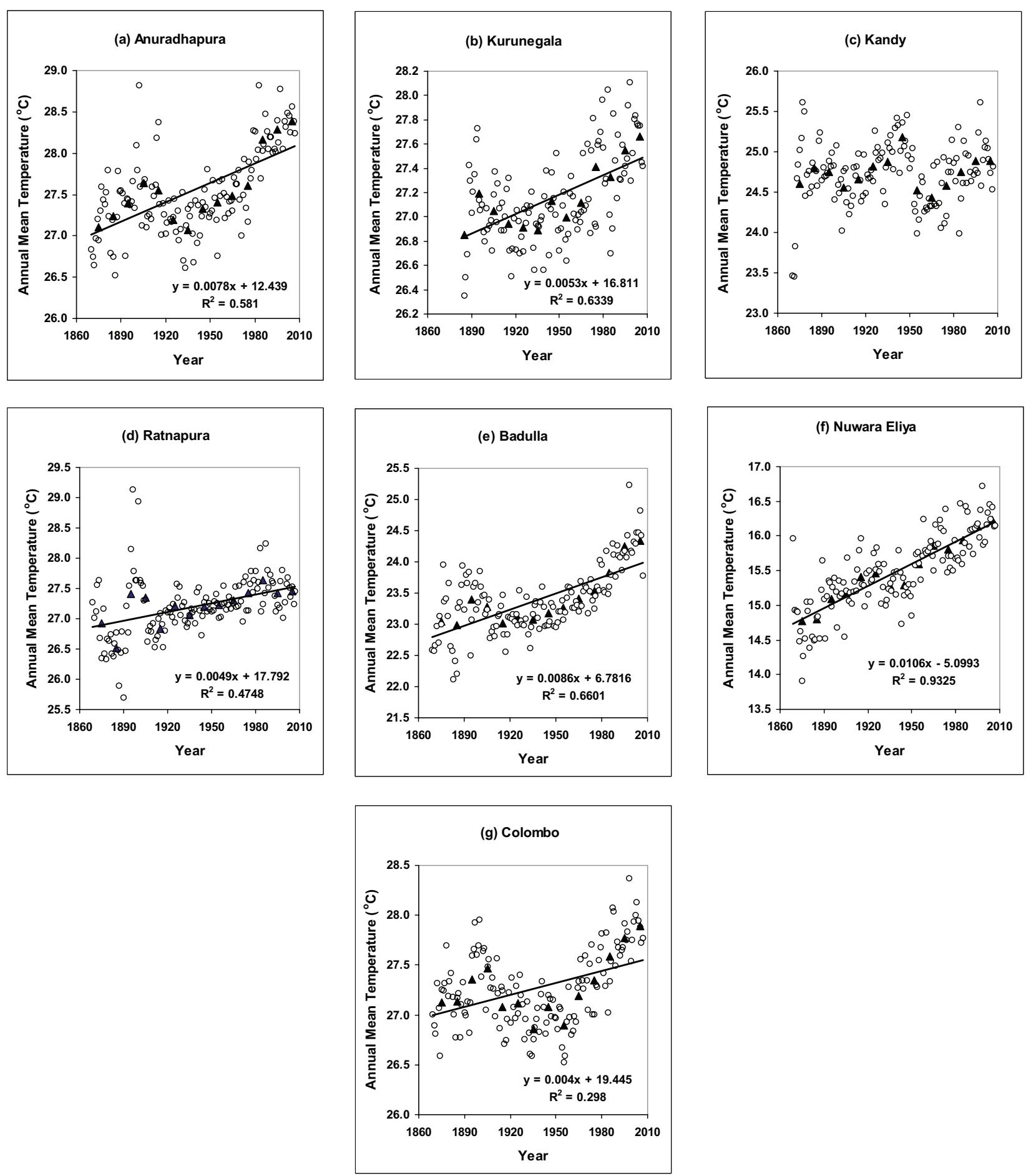

Figure 3: Long-term variation of annual mean air temperatures $(\circ)$ and decadal mean air temperatures $(\boldsymbol{\Delta})$ of selected locations in Sri Lanka. Linear regressions are fitted to the decadal mean emperatures. Note the different vertical scales of different graphs. 
$( \pm 0.019){ }^{\circ} \mathrm{C}$ decade ${ }^{-1}\left(\mathrm{R}^{2}=0.98\right)$ over a 40 -year period from 1870 to 1910 .

In addition to the regression approach described above, the long-term annual air temperature data were subjected to analysis of variance (ANOVA) to see further evidence of climate change. As has been done in the IPCC assessment reports ${ }^{3,5}$ the nearly 140 -year period was divided into three periods as 1870-1949, 1950-1989 and 1990-2007. These three periods broadly signify different phases of global climate change. The first period (i.e. 1870-1949) covers the latter part of the $19^{\text {th }}$ century, the earliest time at which global mean temperature can be accurately defined $^{20}$, and the first half of the $20^{\text {th }}$ century. The rate of warming during this period is considered to be relatively slow when compared to the periods that followed it $3,5,21$. The second period (i.e. 1950-1989), covering most of the second half of the $20^{\text {th }}$ century, is the period in which global warming and climate change emerged as serious issues having multi-faceted impacts on the human society. The early studies on climate change ${ }^{22-25}$ showed that the rate of global warming accelerated during this period in comparison to the preceding period. The third period (i.e. 1990-2007) covers the most recent times during which climate change came to the forefront of the global discussions and fora and research on all aspects of climate change increased substantially. Much of this research work as compiled and summarized by the IPCC in its assessment reports ${ }^{3,5,21}$ point to a growing consensus that the rate of global warming has been highest during this period. Accordingly, variation of the two selected climate indicators, namely air temperature and rainfall, across these three defined periods are examined in this study to detect evidence for climate change in Sri Lanka and quantify its magnitude.

ANOVA was done to examine whether annual mean $T_{a}$ differed significantly between these three periods. Annual mean $\mathrm{T}_{\mathrm{a}} \mathrm{s}$ of each successive period were significantly $(p<0.0001)$ greater than the preceding period at four (i.e. Anuradhapura, Kurunegala, Badulla and Nuwara Eliya) of the seven locations examined (Table 4). Ratnapura and Colombo also showed such increases through successive periods. However, at Ratnapura, the increase from 1950-1989 to 1990-2007 was not statistically significant at $\mathrm{p}=0.05$. Likewise, at Colombo, the increase from 1869-1949 to 1950-1989 was not significant. Particularly notable are the substantial increases in annual mean $\mathrm{T}_{\mathrm{a}} \mathrm{s}$ of the last 18-year period since 1990 at Anuradhapura $\left(0.665^{\circ} \mathrm{C}\right)$, Badulla $\left(0.789^{\circ} \mathrm{C}\right)$ and Colombo $\left(0.572^{\circ} \mathrm{C}\right)$. The highest warming from the 1869-1949 period to the 1950-1989 period was shown at Nuwara Eliya with $0.648 \mathrm{oC}$. In contrast to all other locations examined, Kandy showed a significant $(\mathrm{p}<0.05)$ decrease of annual mean $\mathrm{T}_{\mathrm{a}}\left(0.205^{\circ} \mathrm{C}\right)$ from 1869-1949 to $1950-1989$, which was probably because of the substantial warming experienced in Kandy during the first half of the $20^{\text {th }}$ century (Figure 3.c and Table 3). However, this reduction in annual mean $\mathrm{T}_{\mathrm{a}}$ in Kandy was followed by a significant $(\mathrm{p}<0.05)$ increase $\left(0.317^{\circ} \mathrm{C}\right)$ from 1950-1989 to $1990-2007$.

\section{Shifts in the frequency distribution of annual air temperatures}

Year-to-year variation in $T_{a}$ is one of the factors that make climate change difficult to detect and quantify. While the means of $\mathrm{T}_{\mathrm{a}}$ over different time periods do show significant increases at all locations examined (Table 4), it is essential to determine whether the whole distribution of $\mathrm{T}_{\mathrm{a}}$ has shifted significantly over time. This was investigated by examining different percentile points of the frequency distributions of $\mathrm{T}_{\mathrm{a}}$ during the three time periods defined earlier. In four out of seven locations (i.e. Anuradhapura, Kurunegala, Badulla and Nuwara Eliya), all percentile points in the frequency distribution

Table 4: Variation of annual mean air temperatures of selected locations in Sri Lanka during three defined periods

\begin{tabular}{lcccc}
\hline Location & \multicolumn{4}{c}{ Annual mean air temperature \pm standard error $\left({ }^{\circ} \mathrm{C}\right)$} \\
& $1870-1949$ & $1950-1989$ & $1990-2007$ & CV $(\%)$ \\
\hline Anuradhapura & $27.314 \pm 0.044 \mathrm{a}$ & $27.664 \pm 0.066 \mathrm{~b}$ & $28.329 \pm 0.064 \mathrm{c}$ & 1.163 \\
Kurunegala & $27.008 \pm 0.033 \mathrm{a}$ & $27.214 \pm 0.058 \mathrm{~b}$ & $27.599 \pm 0.056 \mathrm{c}$ & 1.039 \\
Kandy & $24.778 \pm 0.044 \mathrm{a}$ & $24.573 \pm 0.054 \mathrm{~b}$ & $24.890 \pm 0.066 \mathrm{a}$ & 1.565 \\
Ratnapura & $27.061 \pm 0.059 \mathrm{a}$ & $27.399 \pm 0.046 \mathrm{~b}$ & $27.439 \pm 0.053 \mathrm{~b}$ & 1.556 \\
Badulla & $23.136 \pm 0.042 \mathrm{a}$ & $23.506 \pm 0.049 \mathrm{~b}$ & $24.294 \pm 0.079 \mathrm{c}$ & 1.310 \\
Nuwara Eliya & $15.155 \pm 0.044 \mathrm{a}$ & $15.802 \pm 0.052 \mathrm{~b}$ & $16.175 \pm 0.054 \mathrm{c}$ & 2.815 \\
Colombo & $27.152 \pm 0.033 \mathrm{a}$ & $27.255 \pm 0.059 \mathrm{a}$ & $27.827 \pm 0.048 \mathrm{~b}$ & 0.963 \\
\hline
\end{tabular}

Note: For any given location, means with the same letter are not significantly different at $\mathrm{p}=0.05$. Mean separation was done with Duncan's Multiple Range Test. CV - Coefficient of variation.

Source : Department of Meteorology 
of $\mathrm{T}_{\mathrm{a}}$ showed increases through the successive periods considered (Table 5). With the exception of a few percentile points, the same was true for both Colombo and Ratnapura. The only exception at Colombo was the slight reduction in the $5^{\text {th }}$ percentile point from the 1869-1949 period (i.e. period 1) to the 1950-1989 period (i.e. period 2). At Ratnapura, the $5^{\text {th }}, 90^{\text {th }}$ and $95^{\text {th }}$ percentile points showed reductions from the 19501989 period to the 1990-2007 period (i.e. period 3). This observation that either all or the large majority of percentile points has increased shows that the warming through successive periods has occurred because of an overall shift in the year-to-year variation of temperatures rather than a minority of extremely warm years.

At Anuradhapura, the magnitudes of increases from period 1 to 2 were approximately even for all percentile points. However, increases from period 2 to 3 were substantially greater for the lower percentiles (i.e. $5^{\text {th }}, 10^{\text {th }}$ and $25^{\text {th }}$ ), thus indicating that the temperatures of relatively cooler years have increased by a greater magnitude than the temperatures of relatively warmer years. Except for the $90^{\text {th }}$ percentile point, increases of all percentile points from period 2 to 3 were greater than the corresponding increases from period 1 to 2 .

At Kurunegala, it was the higher percentile points (i.e. $75^{\text {th }}, 90^{\text {th }}$ and $95^{\text {th }}$ ) that had shown higher increases from period 1 to 2, indicating greater warming among the relatively warmer years. In contrast, increases from period 2 to 3 were higher in the lower percentile points (i.e. $5^{\text {th }}, 10^{\text {th }}$ and $25^{\text {th }}$ ). At Badulla, substantial increases in all percentile points occurred through both successive periods. In particular, the $95^{\text {th }}$ percentile point has shifted by more than $1^{\circ} \mathrm{C}$ from period 2 to 3 . Moreover, increases of all percentile points from period 2 to 3 were substantially greater than the corresponding increases from period 1 to 2 . In contrast, at Nuwara Eliya, increases of all percentile points from period 1 to 2 were greater than those from period 2 to 3 . Interestingly, during both successive periods at Nuwara Eliya, the lower percentiles (i.e. $5^{\text {th }}, 10^{\text {th }}$ and $25^{\text {th }}$ ) have shown greater increases than

Table 5: Variation of percentile points of the frequency distributions of mean annual temperatures $\left({ }^{\circ} \mathrm{C}\right)$ of selected locations of Sri Lanka during defined periods.

\begin{tabular}{|c|c|c|c|c|c|c|c|c|}
\hline \multirow[t]{2}{*}{ Location } & \multirow[t]{2}{*}{ Period } & \multicolumn{7}{|c|}{ Percentiles in the frequency distribution } \\
\hline & & $5 \%$ & $10 \%$ & $25 \%$ & $50 \%$ & $75 \%$ & $90 \%$ & $95 \%$ \\
\hline \multirow[t]{3}{*}{ Anuradhapura } & $1870-1949$ & 26.692 & 26.775 & 27.096 & 27.313 & 27.521 & 27.733 & 27.954 \\
\hline & 1950-1989 & 27.088 & 27.205 & 27.380 & 27.642 & 27.925 & 28.267 & 28.375 \\
\hline & $1990-2007$ & 28.008 & 28.017 & 28.125 & 28.284 & 28.458 & 28.775 & 29.017 \\
\hline \multirow[t]{3}{*}{ Kurunegala } & $1885-1949$ & 26.567 & 26.692 & 26.875 & 27.000 & 27.158 & 27.367 & 27.425 \\
\hline & 1950-1989 & 26.713 & 26.838 & 26.929 & 27.121 & 27.538 & 27.758 & 27.908 \\
\hline & $1990-2007$ & 27.300 & 27.308 & 27.417 & 27.558 & 27.767 & 27.917 & 28.108 \\
\hline \multirow[t]{3}{*}{ Kandy } & $1870-1949$ & 24.125 & 24.383 & 24.588 & 24.783 & 25.008 & 25.246 & 25.392 \\
\hline & $1950-1989$ & 24.025 & 24.138 & 24.321 & 24.608 & 24.871 & 25.008 & 25.146 \\
\hline & $1990-2007$ & 24.533 & 24.575 & 24.733 & 24.817 & 25.042 & 25.242 & 25.608 \\
\hline \multirow[t]{3}{*}{ Ratnapura } & 1869-1949 & 26.383 & 26.475 & 26.742 & 27.067 & 27.275 & 27.592 & 27.642 \\
\hline & $1950-1989$ & 27.017 & 27.125 & 27.179 & 27.296 & 27.567 & 27.788 & 27.988 \\
\hline & $1990-2007$ & 27.008 & 27.125 & 27.242 & 27.483 & 27.617 & 27.725 & 27.800 \\
\hline \multirow[t]{3}{*}{ Badulla } & 1869-1949 & 22.558 & 22.617 & 22.950 & 23.133 & 23.367 & 23.633 & 23.792 \\
\hline & $1950-1989$ & 23.046 & 23.188 & 23.263 & 23.508 & 23.613 & 23.992 & 24.150 \\
\hline & $1990-2007$ & 23.783 & 23.867 & 24.108 & 24.221 & 24.433 & 24.817 & 25.242 \\
\hline \multirow[t]{3}{*}{ Nuwara Eliya } & 1869-1949 & 14.492 & 14.525 & 14.983 & 15.200 & 15.383 & 15.600 & 15.800 \\
\hline & $1950-1989$ & 15.333 & 15.488 & 15.625 & 15.750 & 15.933 & 16.300 & 16.408 \\
\hline & $1990-2007$ & 15.742 & 15.875 & 16.083 & 16.155 & 16.333 & 16.450 & 16.717 \\
\hline \multirow[t]{3}{*}{ Colombo } & 1869-1949 & 26.750 & 26.775 & 26.958 & 27.133 & 27.317 & 27.600 & 27.667 \\
\hline & $1950-1989$ & 26.633 & 26.821 & 26.979 & 27.283 & 27.529 & 27.763 & 27.933 \\
\hline & $1990-2007$ & 27.542 & 27.592 & 27.675 & 27.758 & 27.942 & 28.133 & 28.375 \\
\hline
\end{tabular}

Source : Department of Meteorology 
the higher percentiles, indicating that the relatively cooler months have warmed more than the relatively warmer months.

Colombo also showed a distinct pattern in its shifts in the percentile points. Firstly, similar to Anuradhapura and Badulla, the increases of all percentile points during the more recent periods (i.e. from period 2 to 3) were substantially greater than those of the earlier periods (i.e. from period 1 to 2). However, in contrast to Anuradhapura and Badulla, it was the relatively warmer years which had shown greater warming from period 1 to 2 . However, the opposite has been the case during the more recent periods, with the lower percentiles showing appreciably greater warming than the higher percentiles.

In Kandy, similar to the pattern shown for annual mean temperatures, all percentile points showed decreases from period 1 to 2 (Table 5). Magnitudes of decreases were relatively greater in the $10^{\text {th }}, 25^{\text {th }}, 90^{\text {th }}$ and $95^{\text {th }}$ percentiles, indicating no 'preferential' cooling in either cooler or warmer months. In contrast to the decreases from period 1 to 2 , all percentile points have shown increases from period 2 to 3. Among these, the highest increases were shown in the $5^{\text {th }}$ and $95^{\text {th }}$ percentiles, showing that warming has occurred in both the coolest and the warmest months.

\section{Long-term variation of monthly air temperature $\left(T_{m}\right)$}

Variation of monthly mean air temperatures $\left(\mathrm{T}_{\mathrm{m}}\right)$ during the three periods defined above are shown in Figure 4. At Anuradhapura (Figure $4 \mathrm{a}$ ), $\mathrm{T}_{\mathrm{m}}$ of all months showed highly significant $(p<0.001)$ increases over the successive periods considered. However, it is notable that the $\mathrm{T}_{\mathrm{m}}$ increases from period 1 (i.e. 1869-1949) to period 2 (1949-1989) during the five-month period from May to September were not statistically significant at $\mathrm{p}=0.05$. This meant that the $\mathrm{T}_{\mathrm{a}}$ increase in Anuradhapura that were observed from period 1 to 2 (Table 4) were primarily due to $T_{m}$ increases during the rest of the months. On the other hand, $\mathrm{T}_{\mathrm{m}}$ increases of all months from period 2 to 3 (1990-2007) were statistically significant $(<0.001)$, showing that the increase of $T_{a}$ during the post- 1990 period was the result of warming during all months of the year. Interestingly, the greatest warming has occurred during a four-month period starting from December $\left(0.736^{\circ} \mathrm{C}\right)$ through January, February and March $\left(\sim 1^{\circ} \mathrm{C}\right)$. It is important to note that this period coincides with a major portion of the main cropping season (i.e. the maha season) of the dry zone of Sri Lanka.

A similar analysis of $T_{m}$ in Kurunegala showed that although all months of the year had warmed from period 1 to 2 (Figure $4 b$ ), significant $(p<0.05$ ) warming during July and August was the principal contributor to the increase of $T_{a}$ (Table 4) during this period. In contrast, significant $(\mathrm{p}<0.05)$ warming during all months except April and June, contributed to increase of $\mathrm{T}_{\mathrm{a}}$ from period 2 to 3 . During this warming, the highest increases in $T_{m}$ $\left(\sim 0.6^{\circ} \mathrm{C}\right)$ have occurred during the three-month period from January to March, again coinciding with the latter part of the maha season. It is also notable that there has been a shift in the warmest month in Kurunegala from April during periods 1 and 2 to March during period 3.

Similar to Anuradhapura and Kurunegala, warming through successive periods has occurred in all months of the year in Badulla (Figure 4f) and Nuwara Eliya (Figure $4 \mathrm{~g}$ ) as well. However, there was one clear difference in the pattern of warming between these two sites. In Badulla, the increases of $\mathrm{T}_{\mathrm{m}}$ of all months from period 2 to 3 were greater than the corresponding increases from period 1 to 2. In contrast, the opposite has occurred in Nuwara Eliya, with the warming from period 1 to 2 being greater than that from period 2 to 3 . This difference is reflected in $T_{a}$ as well (Table 4). At Badulla, the $T_{m}$ increases from period 1 to 2 were not statistically significant $(p=0.05)$ during the four months from November to February, which coincides exactly with the maha season. Therefore, it was the warming during the rest of the year that contributed to the significant increase in $\mathrm{T}_{\mathrm{a}}$ from period 1 to 2 . However, there was significant warming in all months of the year from period 2 to 3 . Interestingly, the period from October to January has shown a lower warming $\left(0.47-0.72^{\circ} \mathrm{C}\right)$ than the rest of the year $(0.80$ $\left.0.97^{\circ} \mathrm{C}\right)$. The highest warming $\left(0.89-0.97^{\circ} \mathrm{C}\right)$ occurred during the four-month period from February to May (Figure 4f).

In Nuwara Eliya, all months have shown significant $(\mathrm{p}<0.05)$ increases in $\mathrm{T}_{\mathrm{m}}$ from period 1 to 2 (Figure $4 \mathrm{~g}$ ), with the highest warming $\left(0.99-1.14^{\circ} \mathrm{C}\right)$ being shown during the three months from February to April. The warming was lower $\left(0.39-0.55^{\circ} \mathrm{C}\right)$ during the seven-month period from May to November. In contrast, warming from period 2 to 3 exceeded $0.5^{\circ} \mathrm{C}$ only during February and March. During the eight-month period from May to December, the warming was less than $0.40^{\circ} \mathrm{C}$ in all months except November, with four months having less than $0.30^{\circ} \mathrm{C}$ warming.

With the exception of the months of February and November from period 1 to $2, \mathrm{~T}_{\mathrm{m}}$ of all months in Colombo increased through successive periods (Figure 4g). Warming in all months was substantially 

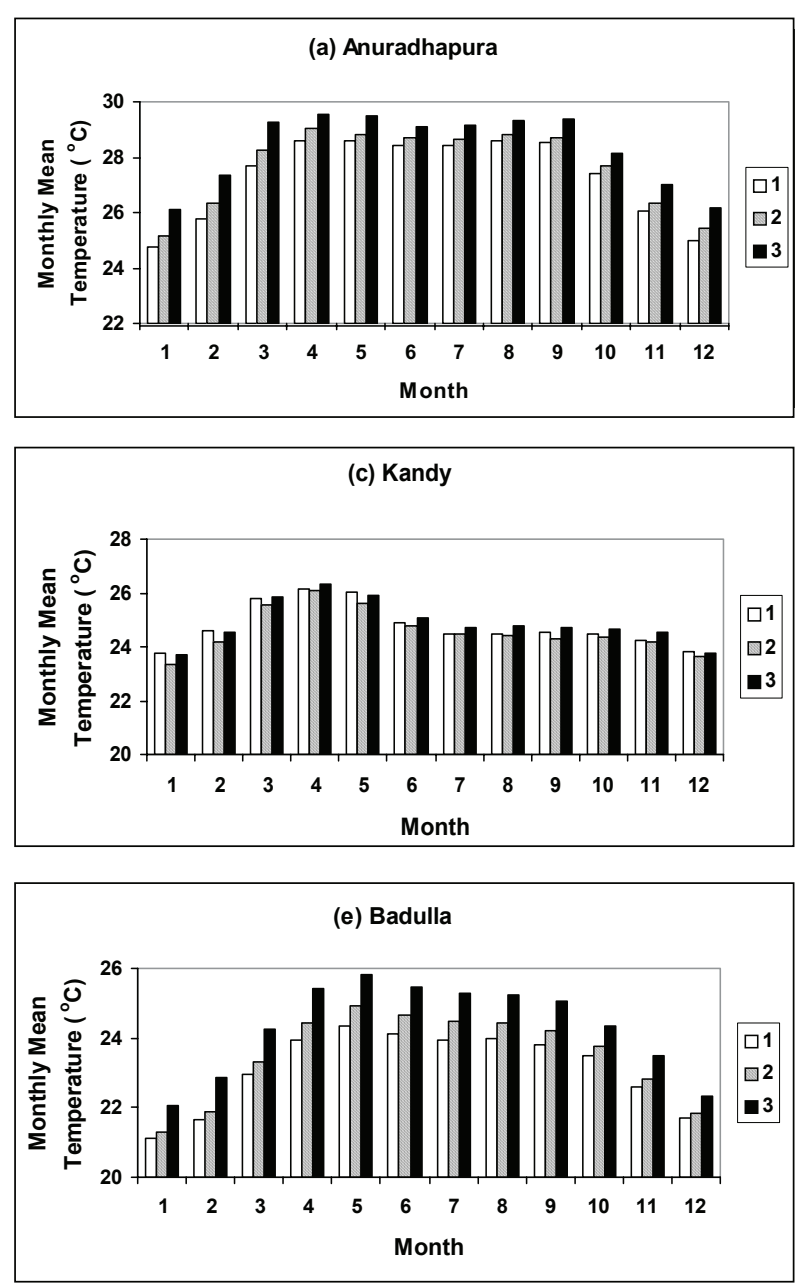
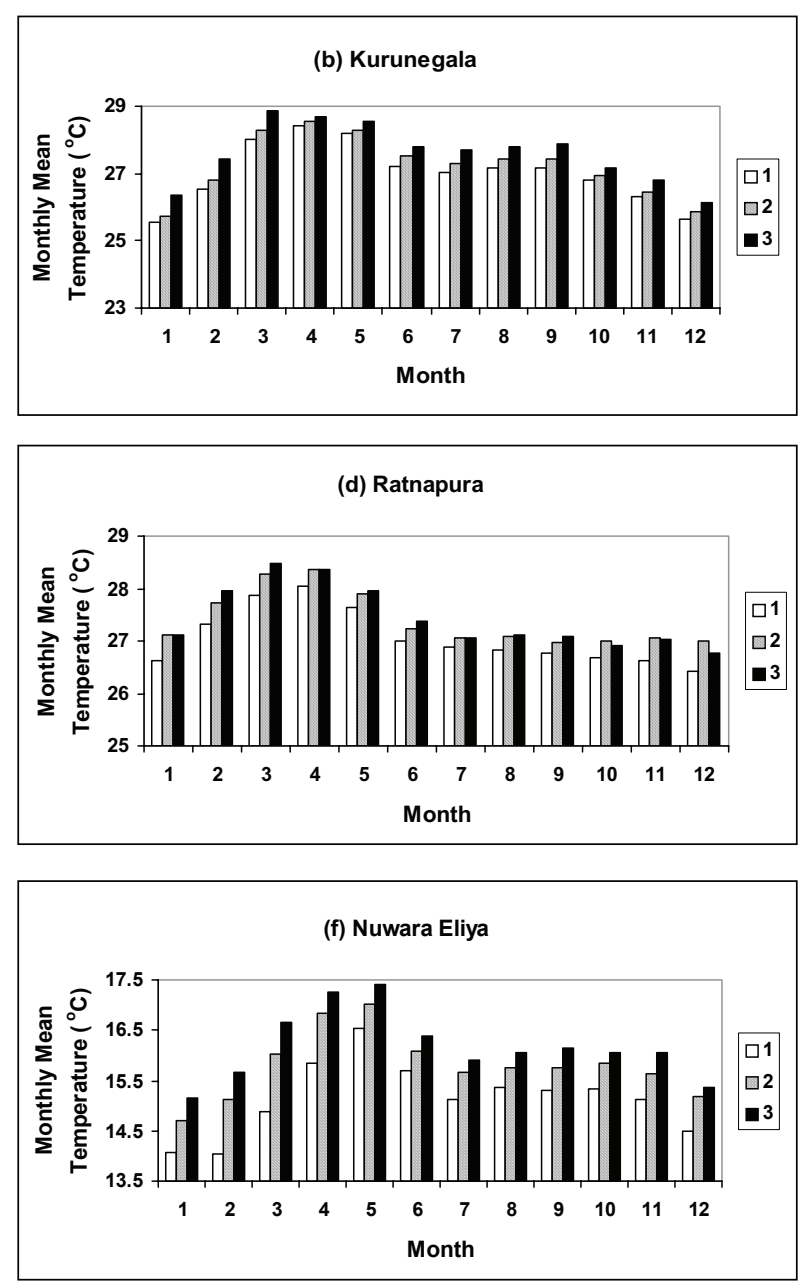

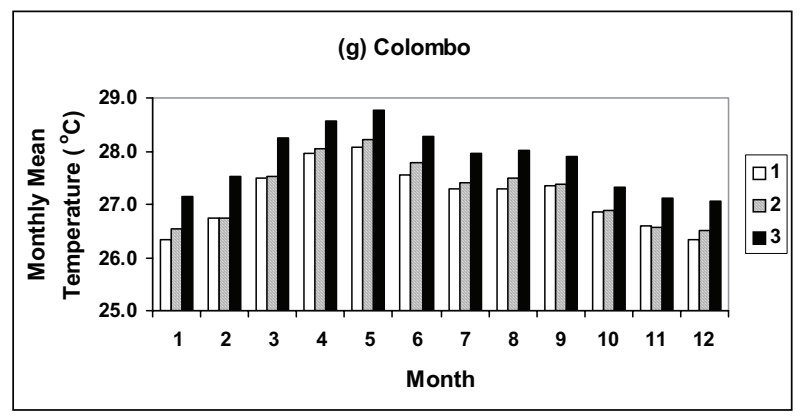

Figure 4: Variation of monthly mean temperatures of selected locations in Sri Lanka during three defined time periods: 1- 1869-1949; 2- 1950-1989; 3- 1990-2007. Note the different vertical scales of different graphs.

greater from period 2 to $3\left(0.44-0.80^{\circ} \mathrm{C}\right)$ as compared to the corresponding warming from period 1 to $2(0.02-$ $\left.0.19^{\circ} \mathrm{C}\right)$. Statistically significant $(\mathrm{p}<0.05)$ increases in $\mathrm{T}_{\mathrm{m}}$ from period 1 to 2 were shown only in January and June. In contrast, $\mathrm{T}_{\mathrm{m}}$ increases from period 2 to 3 exceeded $0.50^{\circ} \mathrm{C}$ in all months except October, with the highest increases $\left(0.62-0.80^{\circ} \mathrm{C}\right)$ being shown in the three months from January to March.

In contrast to Colombo, monthly warming in Ratnapura was lower from period 2 to $3\left(0.01-0.23^{\circ} \mathrm{C}\right)$ as compared to that from period 1 to $2\left(0.18-0.60^{\circ} \mathrm{C}\right)$ 
(Figure $4 \mathrm{~d}$ ). In fact, $\mathrm{T}_{\mathrm{m}}$ showed a decrease from period 2 to 3 during the three months from October to December, while the increases were negligible in the months of January, April and July. None of the $\mathrm{T}_{\mathrm{m}}$ increases from period 2 to 3 were statistically significant $(p<0.05)$. Among the $\mathrm{T}_{\mathrm{m}}$ increases from period 1 to 2 , the highest were in the five months from November to March (0.39$0.60^{\circ} \mathrm{C}$ ). The warmest month of the year in Ratnapura has shifted from April in periods 1 and 2 to March in period 3.

Similar to the annual mean temperatures, variation pattern of monthly mean temperatures in Kandy (Figure 4c) was different from those of all other locations. $\mathrm{T}_{\mathrm{m}}$ of all months showed decreases from period 1 to period 2. Separate analysis of variance of $\mathrm{T}_{\mathrm{m}}$ of different months showed that six months (i.e. March, April, June, July, October and December) did not show significant $(p<0.05)$ variation in $T_{m}$ between the three successive periods considered. $\mathrm{T}_{\mathrm{m}}$ of all months showed reductions $\left(0.05-0.45^{\circ} \mathrm{C}\right)$ from period 1 to 2 , with the three months from January to March $\left(0.27-0.45^{\circ} \mathrm{C}\right)$ and May $\left(0.42^{\circ} \mathrm{C}\right)$ showing comparatively higher reductions. In contrast to the $T_{m}$ reductions from period 1 to 2 , all months showed increases in $T_{m}$ from period 2 to 3 . There was a period of statistically significant $(\mathrm{p}<0.05)$ and relatively higher warming $\left(0.28-0.41^{\circ} \mathrm{C}\right)$ during the five months from May to September. November has also shown a comparatively higher warming $\left(0.39^{\circ} \mathrm{C}\right)$. Another three month period of warming $\left(0.34-0.38^{\circ} \mathrm{C}\right)$ could be identified from January to March. The lowest warming was observed in December with $0.11^{\circ} \mathrm{C}$.

\section{Long-term variation of annual total rainfall $\left(R F_{a}\right)$}

There was considerable year-to-year variation of annual total rainfall $\left(\mathrm{RF}_{\mathrm{a}}\right)$ at all locations (Figure 5). At all locations, there was a 2-3 fold difference between the lowest and the highest $R_{\mathrm{a}} \mathrm{s}$ within the 140-year period. As was done for temperature data, decadal mean $\mathrm{RF}_{\mathrm{a}} \mathrm{s}$ were calculated to detect possible patterns of variation in rainfall. Four out of the seven locations (i.e. Anuradhapura, Kandy, Badulla and Nuwara Eliya) examined showed statistically significant $(\mathrm{p}<0.05)$ linear declining trends of decadal mean $\mathrm{RF}_{\mathrm{a}}$ with time over the entire 140-year period (Figure 4a, c, e and f). The $\mathrm{R}^{2}$ values of these negative linear regressions varied from 0.28 to 0.84 . Kurunegala and Ratnapura also showed negative linear trends of decadal mean $\mathrm{RF}_{\mathrm{a}}$ (Figures $4 \mathrm{~b} \& \mathrm{~d})$. However, these were not statistically significant at $\mathrm{p}=0.05$ and the $\mathrm{R}^{2}$ values were less than 0.20 . In contrast to the rest, decadal mean $\mathrm{RF}_{\mathrm{a}}$ in Colombo showed a positive linear trend (Figure $4 \mathrm{~g}$ ). However, this was not statistically significant $(\mathrm{p}=0.05)$ and the $\mathrm{R}^{2}$ value was only 0.14 .
Over the 140-year period, the highest rate of significant rainfall decline was shown in Nuwara Eliya at $52 \mathrm{~mm}$ decade $^{-1}$ (Table 6), with Kandy showing a decline of $30 \mathrm{~mm}$ decade $^{-1}$. Within the respective trends shown over the entire 140-year period, a period of significant $(p<0.05)$ decline of decadal mean $\mathrm{RF}_{\mathrm{a}}$ could be identified in all locations except Colombo. In particular, Kurunegala has shown a rainfall decline of $121 \mathrm{~mm} \mathrm{decade}^{-1}$ from the $1970 \mathrm{~s}$ onwards. Kandy and Nuwara Eliya have also shown rainfall declines in the range of $64-67 \mathrm{~mm}$ decade ${ }^{-1}$ since $1940 \mathrm{~s}$ and $1920 \mathrm{~s}$ respectively. Interestingly, Anuradhapura and Kandy had experienced faster declines of decadal rainfall during the 50-year period from 1940 to 1990 (i.e. 67 and $86 \mathrm{~mm}$ decade $^{-1}$ respectively) as compared to the respective periods up to 2007. The decadal mean annual rainfall at Ratnapura has shown a decline from $3832 \mathrm{~mm} \mathrm{yr}^{-1}$ in the $1990 \mathrm{~s}$ to $3532 \mathrm{~mm} \mathrm{yr}^{-1}$ in the first decade of the $21^{\text {st }}$ century. Despite its overall positive trend, Colombo also has shown a negative trend at $33 \mathrm{~mm}$ decade $^{-1}$ during the period from $1930 \mathrm{~s}$ onwards. However, the $\mathrm{R}^{2}$ value of this negative trend also is very low at 0.14 . Badulla was the only location among those analyzed that showed an approximately uniform rate of decadal rainfall decline (i.e. $19 \mathrm{~mm} \mathrm{decade}^{-1}$ ) over the entire 140-year period.

As was done for temperature data, the long-term annual rainfall data were also subjected to analysis of variance (ANOVA) to see further evidence of climate change. Mean annual rainfall of the three defined periods showed significant $(p<0.05)$ variation at four (i.e. Anuradhapura, Kandy, Nuwara Eliya and Colombo) out of the seven locations examined (Table 7). In addition, variation of mean $\mathrm{RF}_{\mathrm{a}}$ at Ratnapura during the three defined periods was also very close to being statistically significant at $\mathrm{p}=0.06$. When compared to the $1869-1949$ period, mean $\mathrm{RF}_{\mathrm{a}}$ during the 1950-1989 period showed reductions ranging from $95 \mathrm{~mm} \mathrm{yr}^{-1}$ at Badulla to 307 $\mathrm{mm} \mathrm{yr}^{-1}$ at Nuwara Eliya, representing reductions of 5-13\%. Anuradhapura, Kandy and Ratnapura also showed respective reductions of $8 \%, 11 \%$ and $4 \%$ during the corresponding periods, while Kurunegala and Colombo showed increases of $1 \%$ and $11 \%$. During the 1990-2007 period, mean $\mathrm{RF}_{\mathrm{a}}$ of all locations showed reductions relative to the 1950-1989 period. These ranged from $28 \mathrm{~mm} \mathrm{yr}^{-1}$ at Ratnapura to $202 \mathrm{~mm} \mathrm{yr}^{-1}$ at Kurunegala, representing $0.7 \%$ to $10 \%$ reductions. In addition to Kurunegala, Kandy and Nuwara Eliya have shown mean $\mathrm{RF}_{\mathrm{a}}$ reductions of $121(6 \%)$ and 137 (7\%) $\mathrm{mm} \mathrm{yr}^{-1}$ respectively. During the same period, Anuradhapura, Badulla and Colombo have shown mean $\mathrm{RF}_{\mathrm{a}}$ reductions of $64(5 \%), 62(3 \%)$ and $76(3 \%)$

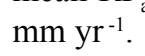



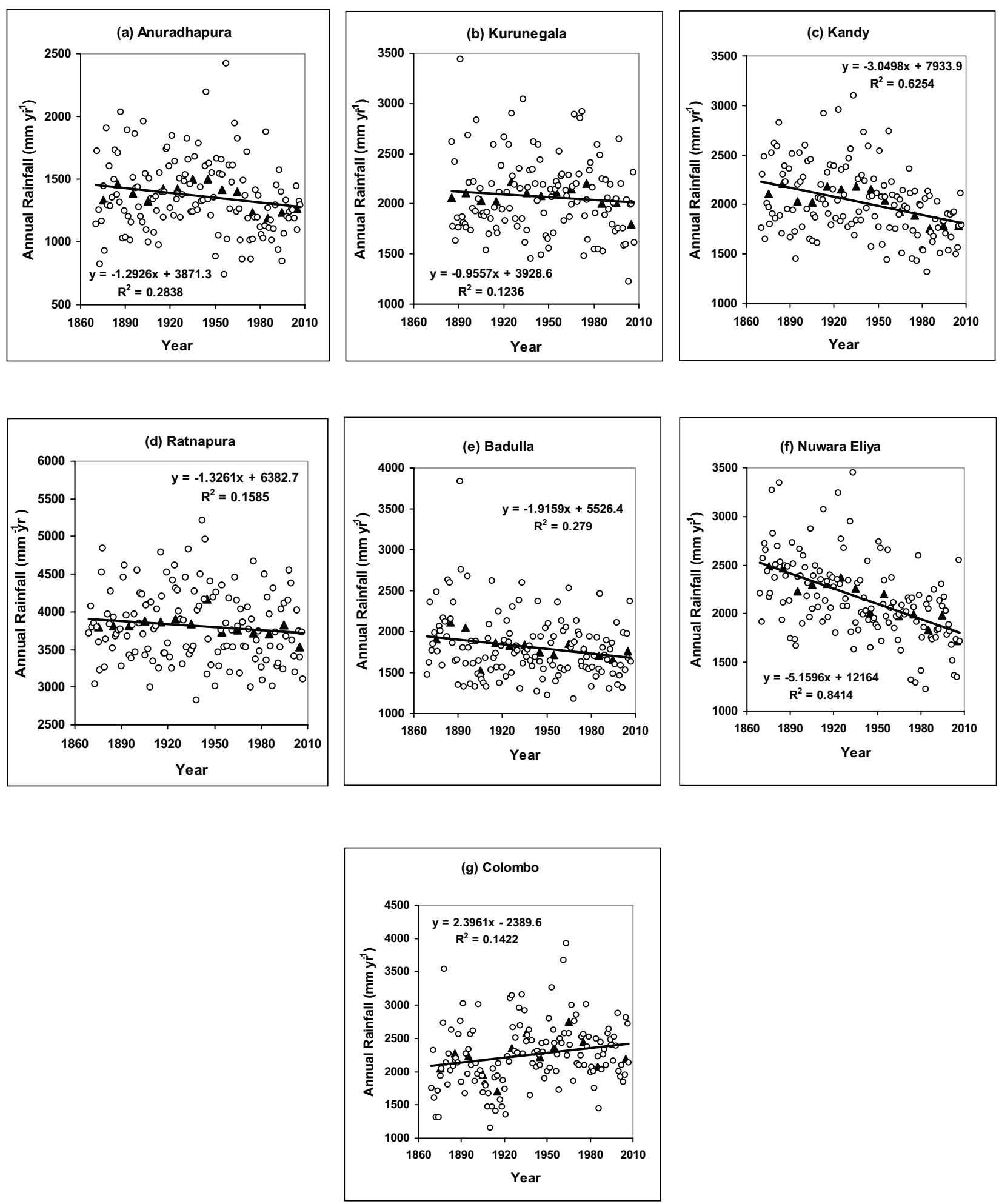

Figure 5: Long-term variation of annual rainfall ( $($ ) and decadal mean rainfall ( $\mathbf{\Delta}$ ) of selected locations in Sri Lanka. Linear regressions are fitted to the decadal mean rainfalls. Note the different vertical scales of different graphs. 
It can be noted that the coefficients of variation (CV) of rainfall data at all locations (Table 7) are much higher than the corresponding $\mathrm{CV}$ values for air temperature data (Table 4). This shows that the year-to-year variation of annual rainfall is substantially greater than the corresponding variation of air temperature.

\section{Shifts in the frequency distribution of annual rainfall}

As was done for annual temperatures, frequency distributions of annual rainfall at different locations were examined to detect significant shifts in the overall pattern of rainfall at a given location. While all locations have shown shifts in their frequency distribution of $\mathrm{RF}_{\mathrm{a}}$ through the successive periods, the percentile points at which the shifts have occurred differed for different locations (Table 8). At Anuradhapura, the reductions of $\mathrm{RF}_{\mathrm{a}}$ from period 1 (i.e. 1869-1949) to period 2 (i.e. 1950-1989) had occurred due to reductions in the lower percentile points (i.e. $5^{\text {th }}, 10^{\text {th }}, 25^{\text {th }}$ and $50^{\text {th }}$ ) indicating that rainfalls had decreased during the relatively drier years. Interestingly, reductions of $\mathrm{RF}_{\mathrm{a}}$ at Anuradhapura from period 2 to 3 (i.e. 1990-2007) had occurred because of reductions in the higher percentile points (i.e. $75^{\text {th }}, 90^{\text {th }}$ and $95^{\text {th }}$ ), showing that rainfall during the wetter years had decreased during the more recent times.

In Kandy, the significant reduction in mean $\mathrm{RF}_{\mathrm{a}}$ from period 1 to 2 had occurred due to substantial reductions at both ends of the distribution (Table 8). However, in magnitude, the reductions at the upper end of the distribution (i.e. 296-380 $\mathrm{mm} \mathrm{yr}^{-1}$ ) were greater than those at the lower end (i.e. 174-213 $\mathrm{mm} \mathrm{yr}^{-1}$ ). During the shift from period 2 to 3 , it was predominantly the decreases at the upper percentiles that had contributed to the observed reduction in mean $\mathrm{RF}_{\mathrm{a}}$. In fact, during this shift, mean $\mathrm{RF}_{\mathrm{a}}$ in the $5^{\text {th }}$ and $10^{\text {th }}$ percentile points had increased slightly showing that drier years have become slightly wetter. At Nuwara Eliya also, substantial reductions are shown at all percentile points of the distribution when mean $\mathrm{RF}_{\mathrm{a}}$ decreased significantly from period 1 to 2 (Tables $7 \&$ 8). Interestingly, the largest reductions were shown at the two extremes (i.e. 437 and $405 \mathrm{~mm} \mathrm{yr}^{-1}$ at the $5^{\text {th }}$ and $95^{\text {th }}$ percentiles) indicating that both the wettest and driest years had become drier. In contrast, during the reduction of mean $\mathrm{RF}_{\mathrm{a}}$ from period 2 to 3 , the largest reduction has occurred at the $50^{\text {th }}$ percentile.

The rainfall distribution shift from period 1 to 2 at Ratnapura occurred more because of reductions at the two ends than in the middle. Interestingly, mean $\mathrm{RF}_{\mathrm{a}}$ at the two ends (i.e. $5^{\text {th }}, 10^{\text {th }}, 90^{\text {th }}$ and $95^{\text {th }}$ percentiles) had increased slightly from period 2 to 3 . Therefore, it was the rainfall reductions in the middle percentiles of the distribution that had caused the reduction in mean $\mathrm{RF}_{\mathrm{a}}$ at Ratnapura from period 2 to 3 . In Badulla, the distribution shift from period 1 to 2 had occurred predominantly at the upper end. However, during the subsequent shift the lower and middle percentiles (i.e. $10^{\text {th }}, 25^{\text {th }}$ and $50^{\text {th }}$ ) had shown relatively greater reductions.

Kurunegala and Colombo had shown increases in mean $\mathrm{RF}_{\mathrm{a}}$ from period 1 to 2 (Table 7). In Colombo, substantial rainfall increases were shown at all percentile points in the distribution (Table 8). Here also, the greatest increases had occurred at the two ends of the distribution. However, in Kurunegala, it was the increases of $\mathrm{RF}_{\mathrm{a}}$ at the middle percentile points (i.e. $25^{\text {th }}$ and $50^{\text {th }}$ ) of the distribution that had caused the slight increase in the mean $\mathrm{RF}_{\mathrm{a}}$. The significant reduction in mean $\mathrm{RF}_{\mathrm{a}}$ in Kurunegala from period 2 to 3 had come about due to substantial reductions at both ends of the distribution. On the other hand, the reduction of mean $\mathrm{RF}_{\mathrm{a}}$ in Colombo from period 2 to 3 had occurred because of substantial reductions in the upper two percentiles (i.e. $90^{\text {th }}$ and $95^{\text {th }}$ ) only.

Overall, the above analysis of shifts in rainfall distributions show that rainfall reductions in the years of extremely lower or higher rainfall have contributed relatively more to the mean rainfall reductions in successive periods than reductions in the years of average rainfall.

\section{Long-term variation of monthly mean rainfall $\left(R F_{m}\right)$}

Figure 6 shows the variation of monthly mean rainfall $\left(\mathrm{RF}_{\mathrm{m}}\right)$ during the three defined periods. At Anuradhapura, there has been a continuous decline of annual mean rainfall $\left(\mathrm{RF}_{\mathrm{a}}\right)$ during the three successive periods (Table 7). However, a notable feature in the $\mathrm{RF}_{\mathrm{m}}$ variation pattern is that rainfall in the months of October and November has not shown an appreciable decline (Figure 6a). It is important to note that these are the two months which bring the highest amounts of rainfall to the lowcountry dry zone through the second inter-monsoon and the North-East monsoon. In contrast, December rainfall, which is the next highest after October and November, has shown a steady decline. Similarly, March, August and September also showed steady decreases in rainfall across the three successive periods. April and May, which are the months of the minor rainy season of the low-country dry zone have also shown decreases of $8 \%$ and $21 \%$ from period 1 (i.e. 1869-1949) to 3 (i.e. 1990-2007). Along with these decreases, $R_{m}$ in the following four-month period from the beginning of June to end of September have also declined by $5 \%$ to $25 \%$. Moreover, rainfall in March, which is the month 
Table 6: Rates of change of decadal mean rainfall during the total period considered and during periods of significant decline for selected locations in Sri Lanka

\begin{tabular}{lccccc}
\hline \multirow{2}{*}{ Location } & \multicolumn{2}{c}{ Total period (1869-2007) } & \multicolumn{2}{c}{ Periods of significant rainfall decline } \\
\cline { 2 - 6 } & $\begin{array}{c}\text { Rate of change of } \\
\text { decadal mean } \mathrm{RF}_{\mathrm{a}} \\
(\mathrm{mm} \text { decade })^{-1} \\
\text { std. error }\end{array}$ & $\begin{array}{c}\mathrm{R}^{2} \text { value } \\
\text { of linear } \\
\text { regression }\end{array}$ & $\begin{array}{c}\text { Rate of change of } \\
\text { decadal mean } \mathrm{RF}_{\mathrm{a}} \\
\left(\mathrm{mm} \mathrm{decade}^{-1}\right) \pm \\
\text { std. error }\end{array}$ & $\begin{array}{c}\mathrm{R}^{2} \text { value } \\
\text { of linear } \\
\text { regression }\end{array}$ & Period \\
\hline Anuradhapura & $-12.92 \pm 5.93$ & 0.28 & $-45.52 \pm 13.04$ & 0.71 & $1940-2007$ \\
Kurunegala & $-9.56 \pm 7.67$ & 0.12 & $-120.57 \pm 29.13$ & 0.90 & $1970-2007$ \\
Kandy & $-30.50 \pm 6.81$ & 0.63 & $-64.36 \pm 11.04$ & 0.87 & $1940-2007$ \\
Ratnapura & $-13.26 \pm 8.82$ & 0.16 & $-85.76 \pm 7.06$ & 0.97 & $1940-1990$ \\
Badulla & $-19.16 \pm 8.89$ & 0.28 & $-15.29 \pm 6.28$ & 0.43 & $1910-2007$ \\
Nuwara Eliya & $-51.60 \pm 6.47$ & 0.84 & $-67.18 \pm 13.12$ & 0.79 & $1920-2007$ \\
Colombo & $+23.96 \pm 16.99$ & 0.14 & $-32.69 \pm 33.18$ & 0.14 & $1930-2007$ \\
\hline
\end{tabular}

preceding the minor rainy season, has also shown a $26 \%$ decline. This means that the lower-rainfall (dry) season in Anuaradhapura has become drier. Hence, the duration available for the minor cropping season (i.e. yala) has become shorter. Moreover, because of the $19 \%$ decline in December rainfall from period 1 to 3, the duration available for the major cropping season (i.e. maha) has also become shorter.

It is worth noting that none of the rainfall declines or increases between the three defined periods in any month of the year at Anuradhapura were statistically significant at $p=0.05$. This was because of the high year-to-year variability of monthly rainfall with $\mathrm{CV}$ values ranging from $36 \%$ (November) to $179 \%$ (June). It is notable that while November, which had the lowest $\mathrm{CV}$, was the wettest month June, which had the highest CV was the driest month.

Changes in the variation pattern of $\mathrm{RF}_{\mathrm{m}}$ at Kurunegala (Figure 6b) were similar to the changes observed at Anuradhapura. $\mathrm{RF}_{\mathrm{m}}$ in four of the high-rainfall months (i.e. October, November, April and May) has not decreased during the three successive periods considered. In contrast, $\mathrm{RF}_{\mathrm{m}}$ in December, June and August has decreased continuously throughout the three periods. Out of these, December and June have been months of comparatively higher rainfall with $\mathrm{RF}_{\mathrm{m}}$ levels around $187 \mathrm{~mm}$ during period 1 (i.e. 1870-1949). By the 19902007 period (i.e. period 3), $\mathrm{RF}_{\mathrm{m}}$ levels have decreased by $60 \mathrm{~mm}(32 \%)$ and $73 \mathrm{~mm}(39 \%)$ in June and December respectively. Rainfall decreases during these two months

Table 7: Variation of mean annual rainfall of selected locations in Sri Lanka during three defined periods.

\begin{tabular}{lcccc}
\hline \multirow{2}{*}{ Location } & \multicolumn{4}{c}{ Mean annual rainfall \pm standard error $\left(\mathrm{mm} \mathrm{yr}^{-1}\right)$} \\
\cline { 2 - 5 } & $1870-1949$ & $1950-1989$ & $1990-2007$ & CV (\%) \\
\hline Anuradhapura & $1419 \pm 30.5 \mathrm{a}$ & $1311 \pm 55.3 \mathrm{ab}$ & $1247 \pm 42.4 \mathrm{~b}$ & 19.5 \\
Kurunegala & $2092 \pm 49.8 \mathrm{a}$ & $2118 \pm 56.9 \mathrm{ab}$ & $1916 \pm 76.4 \mathrm{~b}$ & 17.3 \\
Kandy & $2131 \pm 39.6 \mathrm{a}$ & $1907 \pm 49.0 \mathrm{~b}$ & $1786 \pm 44.1 \mathrm{~b}$ & 12.0 \\
Ratnapura & $3883 \pm 55.5 \mathrm{a} \dagger$ & $3726 \pm 69.5 \mathrm{ab}$ & $3699 \pm 101.3 \mathrm{~b}$ & 10.6 \\
Badulla & $1858 \pm 47.7 \mathrm{a}$ & $1764 \pm 49.5 \mathrm{a}$ & $1702 \pm 68.6 \mathrm{a}$ & 22.8 \\
Nuwara Eliya & $2308 \pm 43.9 \mathrm{a}$ & $2001 \pm 55.2 \mathrm{~b}$ & $1864 \pm 73.5 \mathrm{~b}$ & 18.6 \\
Colombo & $2167 \pm 53.8 \mathrm{~b} \dagger$ & $2408 \pm 78.2 \mathrm{a}$ & $2332 \pm 75.9 \mathrm{ab}$ & 20.9 \\
\hline
\end{tabular}

Note: For any given location, means with the same letter are not significantly different at $\mathrm{p}=0.05$ or $\mathrm{p}=0.10 \dagger$. Mean separation was done with Duncan's Multiple Range Test. CV $=$ Coefficient of variation. 
have contributed substantially to the significant decrease of annual mean rainfall in Kurunegala from period 2 to 3 (Table 7). In addition to the decreases in December, June and August, $\mathrm{RF}_{\mathrm{m}}$ decreases during the months of February, March, July and September from period 2 to 3 have also contributed to the reduction in $\mathrm{RF}_{\mathrm{a}}$ from period 2 to 3. It can also be seen in Kurunegala that while the higher-rainfall (i.e. wet) periods (i.e. October-November and April-May) have not become drier, the lowerrainfall (i.e. dry) periods (i.e. June-August and JanuaryMarch) have become drier over the three defined time periods. Because of the significant decreases of $\mathrm{RF}_{\mathrm{m}}$ in December, the January-March dry period would set in earlier and continue for a longer period. This would mean that the major cropping season (i.e. $\mathrm{maha}$ ) would become shorter with climate change. The range of CV of $\mathrm{RF}_{\mathrm{m}}$ in Kurunegala (38-119\%) was lower than that of Anuradhapura, indicating a lower year-to-year variability. Similar to what was observed at Anuradhapura, the wetter months showed lower $\mathrm{CV}$ of $\mathrm{RF}_{\mathrm{m}}$ and vice versa. In spite of the high $C V$ values, $\mathrm{RF}_{\mathrm{m}}$ changes in Kurunegala between the three successive periods were statistically significant $(\mathrm{p}<0.05)$ in February, June and December.
The most notable feature of the changes in $\mathrm{RF}_{\mathrm{m}}$ of Kandy across the three successive periods (Figure $6 c$ ) is the highly significant $(p<0.001)$ reductions of rainfall in June, July and August. From period 1 to 3, these reductions respectively have been 108, 71 and $67 \mathrm{~mm}$ month $^{-1}$ representing declines of $47 \%, 39 \%$ and $44 \%$. Furthermore, this three-month period is flanked on either side by $22 \%$ and $15 \%$ reductions in rainfall in May and September respectively. Therefore, over this period from May to September, rainfall in Kandy has declined by 303 $\mathrm{mm}$, representing a $35 \%$ decline, from period 1 to 3 . In addition to this period, $\mathrm{RF}_{\mathrm{m}}$ in December and March have also decreased by $21 \%$ and $20 \%$ respectively. Similar to what was observed in Anuradhapura and Kurunegala, October and November rainfall in Kandy also have not shown appreciable declines. Furthermore, April rainfall has shown a $14 \%$ increase from period 1 to 3 . As compared to Anuradhapura and Kurunegala, $\mathrm{CV}$ of $\mathrm{RF}_{\mathrm{m}}$ in Kandy has a narrower range at $40-91 \%$.

The variation pattern of $\mathrm{RF}_{\mathrm{m}}$ in Ratnapura (Figure 6d) showed both similarities and differences to the corresponding patterns in Anuradhapura, Kurunegala

Table 8: Variation of percentile points of the frequency distributions of mean annual rainfalls ( $\mathrm{mm}$ ) of selected locations of Sri Lanka during defined periods.

\begin{tabular}{|c|c|c|c|c|c|c|c|c|}
\hline \multirow[t]{2}{*}{ Location } & \multirow[t]{2}{*}{ Period } & \multicolumn{7}{|c|}{ Percentiles in the frequency distribution } \\
\hline & & $5 \%$ & $10 \%$ & $25 \%$ & $50 \%$ & $75 \%$ & $90 \%$ & $95 \%$ \\
\hline \multirow[t]{3}{*}{ Anuradhapura } & $1870-1949$ & 1006.5 & 1087.5 & 1245.0 & 1371.5 & 1604.0 & 1805.0 & 1902.0 \\
\hline & $1950-1989$ & 863.5 & 952.0 & 1043.5 & 1217.0 & 1543.0 & 1774.5 & 1913.0 \\
\hline & $1990-2007$ & 849.4 & 939.0 & 1192.3 & 1261.4 & 1330.3 & 1457.0 & 1579.0 \\
\hline \multirow[t]{3}{*}{ Kurunegala } & $1885-1949$ & 1615.0 & 1682.0 & 1797.0 & 1956.0 & 2331.0 & 2621.0 & 2838.0 \\
\hline & $1950-1989$ & 1539.0 & 1554.5 & 1886.5 & 2146.5 & 2292.0 & 2556.5 & 2872.5 \\
\hline & $1990-2007$ & 1228.2 & 1584.1 & 1726.5 & 1973.7 & 2055.6 & 2316.1 & 2645.9 \\
\hline \multirow[t]{3}{*}{ Kandy } & $1870-1949$ & 1641.5 & 1698.5 & 1863.5 & 2076.0 & 2386.5 & 2592.5 & 2778.0 \\
\hline & $1950-1989$ & 1443.0 & 1485.5 & 1690.0 & 1976.5 & 2090.5 & 2213.0 & 2453.0 \\
\hline & $1990-2007$ & 1503.6 & 1515.0 & 1669.8 & 1827.6 & 1912.2 & 2035.0 & 2120.7 \\
\hline \multirow[t]{3}{*}{ Ratnapura } & 1869-1949 & 3223.0 & 3281.0 & 3499.0 & 3823.0 & 4240.0 & 4527.0 & 4799.0 \\
\hline & $1950-1989$ & 3017.0 & 3141.5 & 3425.5 & 3739.0 & 4048.0 & 4336.5 & 4483.0 \\
\hline & $1990-2007$ & 3104.5 & 3202.3 & 3323.0 & 3651.8 & 4043.0 & 4381.0 & 4557.8 \\
\hline \multirow[t]{3}{*}{ Badulla } & $1869-1949$ & 1327.0 & 1377.0 & 1579.0 & 1778.0 & 2040.0 & 2386.0 & 2622.0 \\
\hline & $1950-1989$ & 1277.0 & 1424.0 & 1552.5 & 1706.5 & 1953.0 & 2138.0 & 2411.0 \\
\hline & $1990-2007$ & 1302.0 & 1321.8 & 1493.4 & 1645.4 & 1903.0 & 2115.1 & 2370.1 \\
\hline \multirow[t]{3}{*}{ Nuwara Eliya } & 1869-1949 & 1747.0 & 1894.0 & 2015.0 & 2313.0 & 2502.0 & 2767.0 & 3070.0 \\
\hline & $1950-1989$ & 1310.0 & 1523.0 & 1806.0 & 2021.0 & 2160.5 & 2491.0 & 2665.5 \\
\hline & $1990-2007$ & 1347.1 & 1373.8 & 1681.0 & 1830.2 & 2082.5 & 2303.4 & 2555.3 \\
\hline \multirow[t]{3}{*}{ Colombo } & $1869-1949$ & 1408.0 & 1582.0 & 1852.0 & 2128.0 & 2453.0 & 2760.0 & 3025.0 \\
\hline & $1950-1989$ & 1741.0 & 1929.5 & 2068.0 & 2396.0 & 2576.0 & 3005.5 & 3472.0 \\
\hline & $1990-2007$ & 1844.7 & 1932.6 & 2084.8 & 2364.9 & 2577.0 & 2814.0 & 2888.2 \\
\hline
\end{tabular}

Source : Department of Meteorology 
and Kandy (Figures 6 a-c). $\mathrm{RF}_{\mathrm{m}}$ in October, November and April have shown slight increases of 5\%,1\% and $12 \%$ respectively from period 1 to 3 . In contrast to the three locations mentioned above, October and November are not the months, which bring the highest rainfall to Ratnapura. Instead, May and June are the wettest months in Ratnapura and $\mathrm{RF}_{\mathrm{m}}$ of these two months has decreased by $4 \%$ and $19 \%$ respectively. The reduction of $\mathrm{RF}_{\mathrm{m}}$ in June is statistically significant $(\mathrm{p}<0.01)$. In addition, March, August and December have shown rainfall declines of $14 \%, 16 \%$ and $14 \%$ respectively. However, because of the higher $\mathrm{RF}_{\mathrm{m}}$ levels received in Ratnapura, especially during the period from May to November, the $\mathrm{RF}_{\mathrm{m}}$ reductions that have been observed so far are unlikely to cause significant adverse impacts on the durations of cropping seasons or the productivity of major crops. The range of $\mathrm{CV}$ of $\mathrm{RF}_{\mathrm{m}}$ in Ratnapura was the lowest (i.e. $29-61 \%$ ) of the four sites considered so far.

An important distinction in the monthly rainfall pattern in Badulla (Figure 6e) is the substantial contributions from December and January rainfalls, which are almost on par with those in October and November. Interestingly, $\mathrm{RF}_{\mathrm{m}}$ in December and January have declined by $13 \%$ and $11 \%$ respectively from period 1 to 3. Furthermore, March and June have shown significant $(p<0.05) \mathrm{RF}_{\mathrm{m}}$ declines of $48 \%$ and $17 \%$ respectively, while August has shown a 19\% decline. Because of the reductions in December and January rainfalls, the maha season in Badulla has become shorter. The months which bring rains for the yala season (i.e. April and May) have also shown $\mathrm{RF}_{\mathrm{m}}$ reductions of $8 \%$ and $13 \%$ respectively. When taking into consideration, the $48 \%$ and $17 \%$ reductions of the two flanking months (i.e. March and June) as well, it is clear that the yala season has also become shorter. In fact, during the sixmonth period from March to August, rainfall in Badulla has decreased by $119 \mathrm{~mm}$, representing a 19\% decline, from period 1 to 3 . The $\mathrm{CV}$ range of $\mathrm{RF}_{\mathrm{m}}$ in Badulla was $43-107 \%$, which was lower than the corresponding ranges in Anuradhapura and Kurunegala, but higher than those in Ratnapura and Kandy.

The variation pattern of $\mathrm{RF}_{\mathrm{m}}$ in Nuwara Eliya (Figure 6f) has many features which are similar to that in Kandy. From period 1 to 3 , there have been highly significant $(p<0.001)$ reductions of $\mathrm{RF}_{\mathrm{m}}$ in June and July, which were the months of highest rainfall in Nuwara Eliya during period 1. The respective $\mathrm{RF}_{\mathrm{m}}$ reductions in June and July were 95 and $109 \mathrm{~mm}$, amounting to declines of $32 \%$ and $38 \%$. In addition, there were significant $(\mathrm{p}<0.01)$ $\mathrm{RF}_{\mathrm{m}}$ reductions in March and August with $44 \%$ and
$36 \%$ respectively. Further reductions of $12 \%, 15 \%, 14 \%$ and $17 \%$ have occurred in April, May, September and December respectively. November and February have been the only two months, that have not shown reductions in $\mathrm{RF}_{\mathrm{m}}$ from period 1 to 3 . As in Kandy, Nuwara Eliya also showed a substantial rainfall reduction of $336 \mathrm{~mm}$, which represented a 29\% reduction, during the five month period from May to September. Furthermore, during the eight month period from March to October, rainfall has reduced by $415 \mathrm{~mm}$, causing a $25 \%$ reduction, from period 1 to 3 . Because of these changes, the months of highest rainfall in Nuwara Eliya have shifted from June and July during period 1 (i.e. 1869-1949) to October and November during period 3 (i.e. 1990-2007) (Figure 6f). The CV range of $\mathrm{RF}_{\mathrm{m}}$ in Nuwara Eliya of $42-87 \%$ was on par with the range shown in Kandy (i.e. 40-91\%).

It was shown earlier that mean annual rainfall $\left(\mathrm{RF}_{\mathrm{a}}\right)$ in Colombo had increased significantly $(\mathrm{p}<0.05)$ from period 1 (1869-1949) to 2 (1950-1989) (Table 7), but had decreased from period 2 to 3 . Therefore, when $\mathrm{RF}_{\mathrm{m}}$ changes from period 1 to 3 are considered (Figure $6 \mathrm{~g}$ ), only March and April have shown declines in rainfall, which amounted to $23 \%$ and $9 \%$ respectively. Among the rest of the months which had shown rainfall increases, September has shown the highest $\mathrm{RF}_{\mathrm{m}}$ increase of 93 $\mathrm{mm}$, representing a $69 \%$ increase, from period 1 to 3 . When $\mathrm{RF}_{\mathrm{m}}$ changes from period 2 to 3 are considered, decreases have been shown during the four-month period from February to May and in December. Among these months, February, March and December have shown decreases of $28 \%, 38 \%$ and $18 \%$ respectively. Among the rest of the months, which have shown increases, January has shown the highest with a $21 \%$ increase in $\mathrm{RF}_{\mathrm{m}}$. The CV range of $\mathrm{RF}_{\mathrm{m}}$ in Colombo (i.e. 45-99\%) was also similar to those of Kandy and Nuwara Eliya.

When the monthly mean rainfall variations across all locations are considered, the $\mathrm{CV}$ of $\mathrm{RF}_{\mathrm{m}}$ changes through the three successive periods shows a negative curvilinear relationship with $\mathrm{RF}_{\mathrm{m}}$ (Figure 7). This affirms the earlier observations made for individual locations that variability of rainfall is greater when $\mathrm{RF}_{\mathrm{m}}$ is lower. Figure 7 shows that the $\mathrm{CV}$ remains below $40 \%$ when $\mathrm{RF}_{\mathrm{m}}$ is greater than $200 \mathrm{~mm} \mathrm{month}^{-1}$. CV begins to increase significantly when $\mathrm{RF}_{\mathrm{m}}$ drops below the above threshold.

\section{Relationship between mean annual temperature $\left(T_{a}\right)$ and rainfall $\left(R F_{a}\right)$}

The relationships between $\mathrm{T}_{\mathrm{a}}$ and $\mathrm{RF}_{\mathrm{a}}$ and the strength of those relationships at different locations were examined by regression and correlation analysis respectively. At 

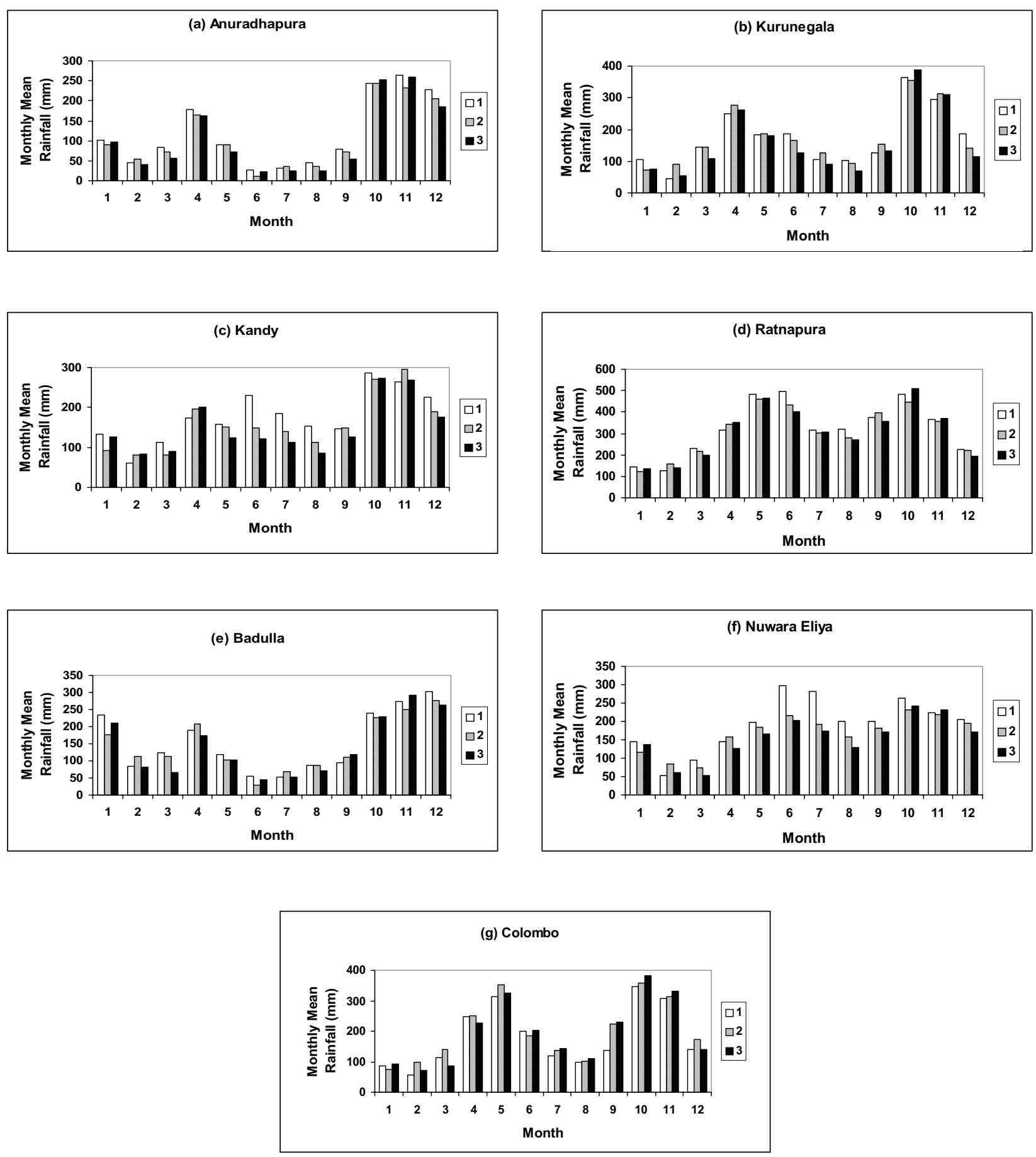

Figure 6: Variation of monthly mean rainfalls of selected locations in Sri Lanka during three defined time periods: 1- 1869-1949; 2- 1950-1989; 3-1990-2007. Note the different vertical scales of different graphs. 
all locations, $\mathrm{RF}_{\mathrm{a}}$ showed decreasing trends, of varying strengths, with increasing $\mathrm{T}_{\mathrm{a}}$ (Figure 8). The correlation coefficient, which is a measure of the strength of the relationship, was statistically significant $(p<0.05)$ in three (i.e. Anuradhapura, Kurunegala and Nuwara Eliya) of the seven locations examined. Slope of the regressions (i.e. decrease of $\mathrm{RF}_{\mathrm{a}}$ per unit increase of $\mathrm{T}_{\mathrm{a}}$ ), showed considerable variation between locations. It was highest in Nuwara Eliya (i.e. $371 \mathrm{~mm}^{\circ} \mathrm{C}^{-1}$ ) and lowest in Colombo (i.e. $58 \mathrm{~mm}^{\circ} \mathrm{C}^{-1}$ ).

\section{Possible influence of the El Niño phenomenon on rainfall variation in Sri Lanka}

El Niño Southern Oscillation (ENSO) is a coupled oceanatmosphere phenomenon that influences the climate variability, especially the seasonal variability of rainfall, of the tropical zone of the world ${ }^{26-30}$. Therefore, it is worth examining whether the relatively high variability of rainfall observed at all locations examined in this paper is related to the occurrence of ENSO. It has also been suggested that the frequency of ENSO may have

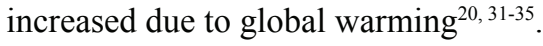

\section{The ENSO phenomena and their dynamics}

ENSO has two phases: the "normal" or cooler phase and the warmer phase, El Niño. Sea surface temperature (SST) differentials in the Pacific Ocean around the equator (approximately between $5^{\circ} \mathrm{N}$ and $5^{\circ} \mathrm{S}$ ) along with

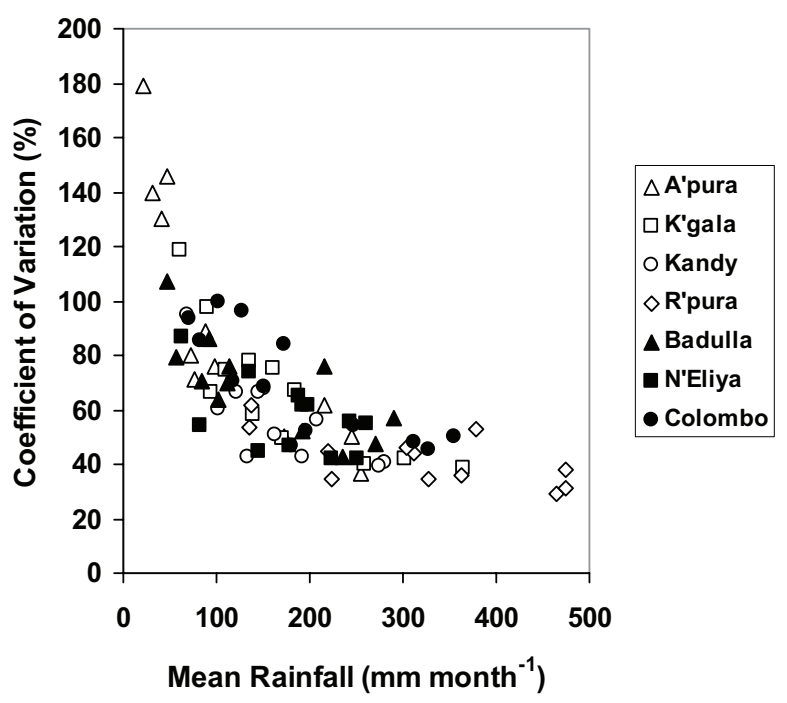

Figure 7: Relationship between mean rainfall of different months of the year and coefficient of variation of monthly rainfall between the three defined periods in selected locations of Sri Lanka. The best-fitting curve through all data points is $\mathrm{CV}=765.72 \mathrm{RF}_{\mathrm{m}}-0.503$ with $\mathrm{R}^{2}=0.759$. the varying strength of atmospheric circulation patterns, specifically East-West trade winds, are responsible for the occurrence of the two phases of ENSO. During the normal phase, the easterly trade winds push warm sea surface water from the Eastern Equatorial Pacific (EEP) near the coast of Peru to the Western Equatorial Pacific (WEP) near Indonesia. Hence, an SST differential is created, with the highest being in the WEP and the lowest in the EEP. This SST differential is enhanced by the upwelling (i.e. transfer from deeper to surface layers) of cold water in the EEP by the Walker circulation pattern ${ }^{32,34}$. The Bjerknes positive feedback ${ }^{36}$ enhances the SST differential by creating higher atmospheric pressure above the EEP to maintain easterly trade winds. During this normal phase, the warmer SSTs in the WEP promote evaporation and provide rainfall to East and South-East Asia (i.e. rainforests of Indonesia) while dry conditions prevail in the EEP and Tropical South America (e.g. Peru). When the SSTs of the cooler phase are unusually cold, the "normal phase" is called a La Niña, the extreme opposite of El Niño.

An El Niño phase is created when the easterly trade winds slacken or reverse during certain years. When this happens, the warmer sea water accumulated in the WEP is sent back towards the EEP and thereby warms the SST near the coast of Peru. The Walker circulation is weakened or breaks down completely and thereby the upwelling of cold water is also cut off. The Bjerknes feedback now works in the reverse direction allowing more warm water to move to the EEP. Hence, during an El Niño phase, droughts occur in East and South-East Asia (leading to forest fires in Indonesia) while severe rainstorms occur in the EEP (i.e. Haiti in the French Polynesia and Peru). In addition, an El Niño episode causes climate variability over a larger global scale by causing droughts in Australia and South-Eastern Africa (i.e. Zimbabwe), unusually warm periods in Canada and North-Eastern USA and heavy un-seasonal rainfall in South-Eastern USA and Argentina.

Although considerable advances have been made, long-term prediction of the time of onset and duration of an El Niño is still difficult ${ }^{37-39}$. Historical evidence shows that an El Niño phase can occur every $2-7$ years, lasting over 6-12 months, but may continue for up to 18 months. Two of the strongest El Niños (known as Super El Niños) of the $20^{\text {th }}$ century occurred during its last two decades in 1982-83 and 1997-98. The 1990s saw an unusually rapid succession of El Niños in 1991-92, 1993, 199495 and 1997-98. Usually, the SST warming in the EEP starts during the second half of the year and continues for varying periods during the first half of the following year. Usually, when a La Niña event occurs, it follows 
an El Niño. However, all El Niños are not followed by a La Niña. Hence, El Niños occur more frequently than La Niñas.

\section{Strength of ENSO phenomena}

TheUSNationalOceanic andAtmosphericAdministration (NOAA) uses the deviation of SST in the $5^{\circ} \mathrm{N}-5^{\circ} \mathrm{S}, 120^{\circ}$ $-170^{\circ} \mathrm{W}$ region from its mean during the 30 -year period from 1971 to 2000 to quantify the strengths of El Niño and La Niña events. This is called the Oceanic Niño Index (ONI) and is calculated using three-month running means of SST. When the ONI exceeds the threshold of $+0.5^{\circ} \mathrm{C}$ or $-0.5^{\circ} \mathrm{C}$ for five consecutive overlapping periods an El Niño or a La Niña respectively is recognized.

\section{Possible impacts of ENSO phenomena on the climate of} Sri Lanka

Sri Lanka receives most of its rainfall from the two monsoons, the South-West Monsoon from May to September and the North-East Monsoon from November to January. One of the identified impacts of El Niño is the weakening of the South-West Monsoon in India ${ }^{30,40-}$ 42. According to compilations of long-term observations by the US NOAA, a region in South-East Asia including the Indian Peninsula and Sri Lanka could experience anomalously warmer temperatures during the December - February period of an El Niño year ${ }^{43}$. On the other hand, the Indian Peninsula could experience unusually dry conditions (i.e. a weaker South-West Monsoon) during June - August which follow an El Niño event. However, this zone of anomalously dry weather does not extend to the Southern tip of India or Sri Lanka. In contrast, a large region in the South- and South-Eastern and East Asia, including Sri Lanka, may experience unusually cooler temperatures in June-August during a La Niña episode $^{44}$. On the other hand, the climate of the Indian Peninsula and Sri Lanka is not expected to be affected in December-February during a La Niña episode.

In addition to ENSO impacts, a phenomenon similar to the El Niño in the Pacific has been reported in the Indian Ocean as well ${ }^{45}$ based on analysis of ocean and atmospheric data over a period of 40 years. This has been named the Dipole Mode Event (DME) with unusually low SSTs in the Eastern Indian Ocean off Sumatra and high SSTs in the Western Indian Ocean along with accompanying wind and rainfall anomalies. This has been shown to be unique and inherent to the Indian Ocean and is independent of ENSO. When the DME is active, rainfall increases are predicted in the Western Indian Ocean while droughts are predicted in the Eastern part. Accordingly, rainfall in the South Western part of Sri Lanka (i.e. wet zone) is predicted to increase while rainfall to the rest of Sri Lanka is predicted to decrease. An internal ocean-atmosphere dynamic was identified to explain the strong seasonal anomalies in Indian Ocean SSTs and wind and precipitation patterns that occurred in 1997-98 ${ }^{46}$ (coinciding with the super El Niño of the same period). It was shown that the Indian Ocean SST at present is warmer than at any time during the last 100,000 years, primarily due to rapid warming during the last 3-4 decades ${ }^{20}$.

\section{Evidence for possible influences of El Niño on the rainfall of Sri Lanka}

In order to see whether El Niño episodes have had a discernible influence on the rainfall variability of Sri Lanka, monthly and annual anomalies of rainfall during the relevant periods were analyzed. The periods of El Niño since 1950 were identified from the ONI records of the US NOAA ${ }^{47}$. Monthly rainfall data were obtained from the seven selected locations. The period since 1950 was divided into two, i.e. from 1950 to 1989 (Period 1) and from 1990 to 2007 (Period 2), to identify whether any possible influence of $E l$ Niño on rainfall has changed with 'rapid climate change' that has been observed since $1990^{3}$. In each location, monthly mean temperature was calculated for each month during the two identified periods. As El Niño occurs during the second half of a given year, its possible effects were examined on the rainfall of the following year. Possible effects of an El Niño on monthly rainfall of a given month of the following year was calculated as a 'Monthly Rainfall Anomaly (MRA)',

$\mathrm{MRA}=\mathrm{RF}_{\mathrm{i}}-\mathrm{RF}_{\mathrm{m}}$

where, $\mathrm{RF}_{\mathrm{i}}$ is the rainfall of a given month $\mathrm{i}$ in the year following an El Niño event and $\mathrm{RF}_{\mathrm{m}}$ is the long-term mean rainfall of the same month of during the period under consideration (i.e. period 1 or 2). An analysis of variance (ANOVA) was done to test whether MRA of each month differed significantly between 'post-El Niño years' (i.e. the year following an El Niño event) and 'normal' years. Variation of MRA in normal and postEl Niño years for the seven selected locations are given in Figure 9. The respective anomalies of annual rainfalls (ARA) of normal and post-El Niño years during the two periods are given in Table 9.

Post-El Niño years had negative ARAs in the majority of locations and periods (Table 9), indicating that the occurrence of an El Niño event reduced the annual rainfall $\left(\mathrm{RF}_{\mathrm{a}}\right)$ below the long-term average $\mathrm{RF}_{\mathrm{a}}$ during the following year. The only exceptions to this trend were in Ratnapura (Figure 9h) and Colombo (Figure 9n) 

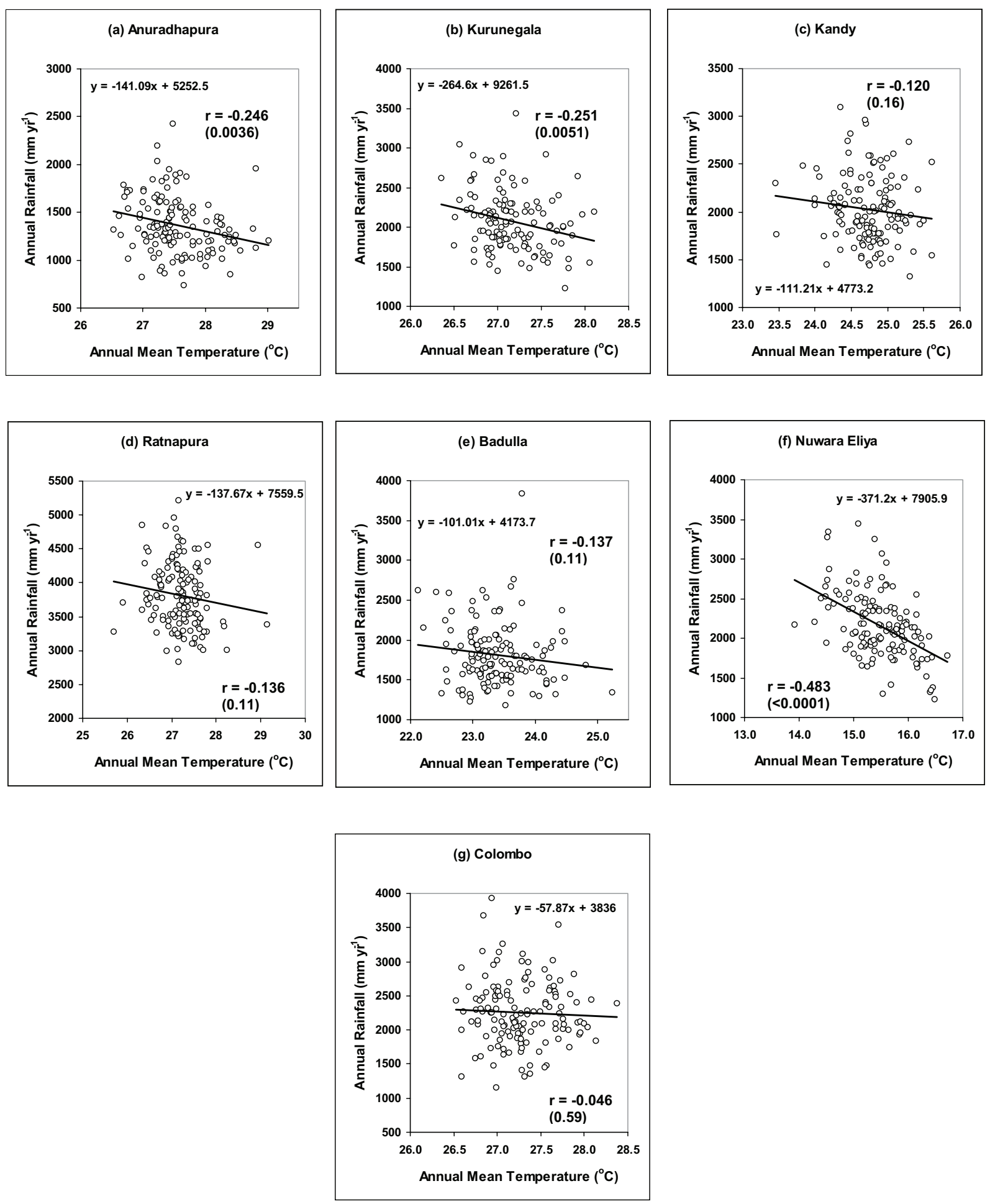

Figure 8: Relationships between annual rainfall and annual mean temperature of selected locations in Sri Lanka. $r$ is the linear correlation coefficient between the two variables. Probability of $r$ being greater than zero is shown in parentheses. Note the different vertical and horizontal scales of different graphs. 
during period 2 (i.e. 1990-2007), where the ARAs were positive. In all other locations, the difference between ARAs of post-El Niño years and normal years, which is the mean difference in $\mathrm{RF}_{\mathrm{a}}$ between post-El Niño and normal years, widened from period 1 (i.e. 1950-1989) to 2. This implies that the possible impacts of El Niño events in reducing rainfall in the subsequent year have increased since 1990. The highest increase of the ARA difference from period 1 to 2 was observed in Badulla (i.e. from 125 to $305 \mathrm{~mm} \mathrm{yr}^{-1}$ ) (Table 9).

Months in which rainfall reductions have occurred in post-El Niño years can be identified by examining the variation of MRAs (Figure 9). MRA of June was negative in all locations during period 1 , showing that June rainfall had decreased below the long-term average during the year that follows an El Niño event. As June rainfall is brought by the South-West monsoon, this observation shows that El Niño had weakened the SouthWest monsoon in Sri Lanka during 1950-1989. During this period, the magnitude of reduction of June rainfall in post-El Niño years varied for different locations, with Nuwara Eliya showing the highest reduction and Anuradhapura, the lowest. July rainfall also had shown a reduction in post- $E l$ Niño years during period 1 in all locations except Anuradhapura and Badulla (Figues 9a and 9i). However, both these locations have very low rainfalls in July even in normal years because they do not receive much rainfall from the South-West monsoon (Figures 6a and 6e). This provides further evidence that El Niño had weakened the South-West monsoon during period 1. However, during period 2 (i.e. from 1990 to 2007), this effect of El Niño has almost completely disappeared with only a few locations showing rainfall reductions of less than $10 \mathrm{~mm}$ in June and July during post-El Niño years (Figures $9 \mathrm{~b}, \mathrm{~d}, \mathrm{f}, \mathrm{h}, \mathrm{j}, \mathrm{l}$ and n). On the other hand, all locations except Nuwara Eliya, have shown increases in post-El Niño July rainfall during period 2. Particularly, Ratnapura and Colombo have shown substantial post-El Niño rainfall increases in May, June and July which contributed to the positive ARAs of these two locations during period 2 (Table 9). In fact, post-El Niño rainfall in Ratnapura has increased over a continuous six-month period from April to September (Figure 9h).

In addition to reductions in June and July rainfalls, January and February have also shown negative MRAs during period 1 in all locations except Colombo. In contrast to the reductions in June and July rainfalls during period 1 , which were reversed during period 2, the post-El Niño reductions in January and February rainfall have occurred during both periods. These reductions are substantial in Anuradhapura, Badulla and Kurunegala, which are the sites receiving a significant proportion of their annual rainfall from the North-East monsoon. However, during period 2, Kandy has also shown appreciable reductions in January and February rainfall immediately following an $\mathrm{El} \mathrm{Niño} \mathrm{event.}$

It appears that an El Niño event during the second half of a given year could decrease even the rainfall of the second half of the following year. Figure 9 shows that during period 1 (1950-1989), a majority of locations examined showed post-El Niño reductions in September and November rainfall. With a few exceptions, these reductions in September and November rainfall have continued during period 2 (1990-2007) as well.

During period 1 , only a few locations had shown post-El Niño reductions in October and December rainfall. However, during period 2, all locations have

Table 9: Anomalies of annual rainfall $\dagger(\mathrm{mm})$ in post-El Niño years and normal years in selected locations of Sri Lanka during two defined periods

\begin{tabular}{|c|c|c|c|c|c|c|}
\hline \multirow[t]{2}{*}{ Location } & \multicolumn{3}{|c|}{$1950-1989$} & \multicolumn{3}{|c|}{$1990-2007$} \\
\hline & Normal & El Niño & Difference $\ddagger$ & Normal & El Niño & Difference \\
\hline Anuradhapura & +47.9 & -111.8 & -159.8 & +70.4 & -140.8 & -211.2 \\
\hline Kurunegala & +28.3 & -66.0 & -94.3 & +49.2 & -98.3 & -147.5 \\
\hline Kandy & +64.6 & -118.4 & -183.0 & +74.5 & -173.8 & -248.3 \\
\hline Ratnapura & +79.3 & -185.1 & -264.4 & -45.6 & +91.2 & +136.8 \\
\hline Badulla & +37.5 & -87.5 & -125.0 & +101.8 & -203.5 & -305.3 \\
\hline Nuwara Eliya & +53.3 & -124.5 & -177.8 & +90.2 & -180.3 & -270.5 \\
\hline Colombo & +34.6 & -80.8 & -115.4 & -19.8 & +39.5 & +59.2 \\
\hline
\end{tabular}

Note: †Annual Rainfall Anomaly (ARA) is the difference between rainfall in a given year and the annual mean rainfall of the period under consid-

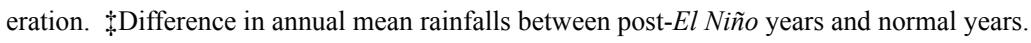



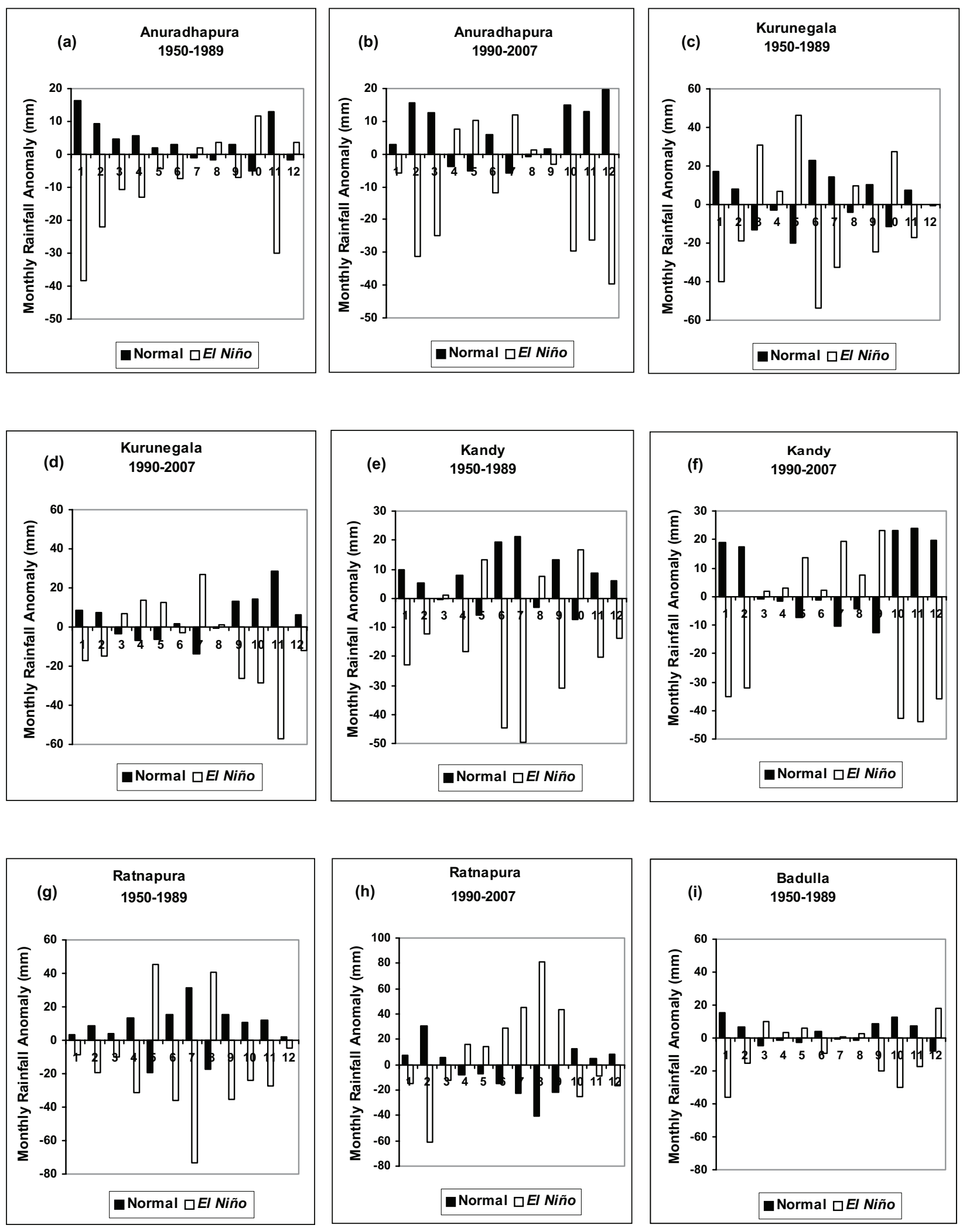

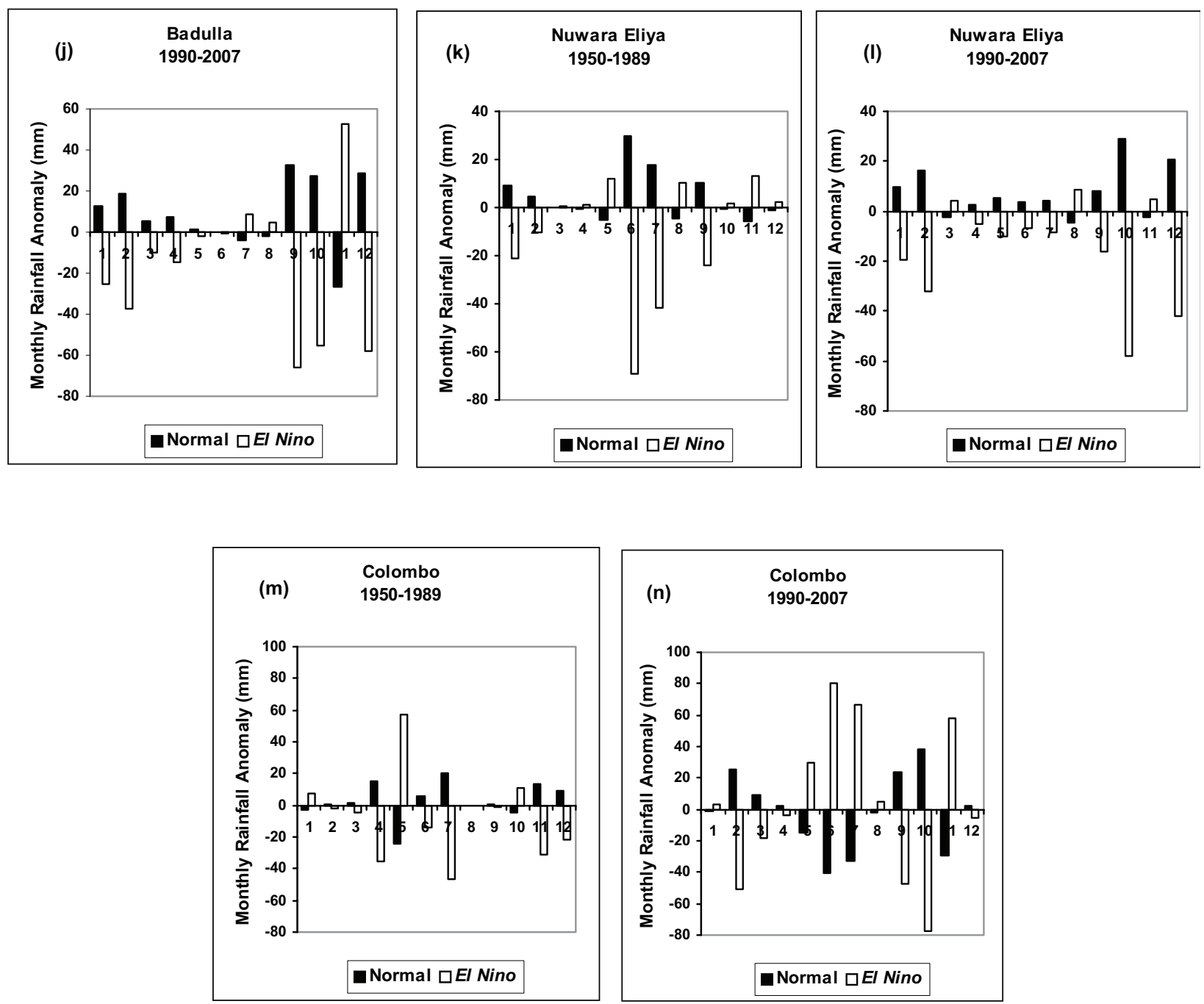

Figure 9: Monthly rainfall anomaly (MRA) of selected locations in 'normal' and 'post-El Nino' years for two identified periods, from 1950 to 1989 (a, c, e, g, i, k, m) and from 1990 to 2007 (b, d, f, h, j, l, n). For a given period, MRA is calculated as the difference between monthly rainfall of a given month of a given year and the mean monthly rainfall of the respective month over the identified period.

shown reductions in October and December rainfall in the year that has followed an El Niño event. Therefore, these trends show that, with climate change, the El Niño may be influencing not only the South-West monsoon but also the North-East monsoon of the year that follows it. This could have far reaching impacts on Sri Lankan agriculture which is heavily dependent on the monsoons.

\section{CONCLUSION}

The main objective of this paper was to examine evidence supporting (or rejecting) the case for climate change in Sri Lanka. The foregoing analysis of long-term air temperature data provide strong evidence that significant and systematic warming of the atmosphere has occurred in all climatic zones of Sri Lanka. What is even more significant is the finding that the rates of warming that have occurred in the majority of locations have exceeded the global average rate of warming. In the majority of locations, reductions in rainfall have accompanied warming of the lower atmosphere. However, the evidence for rainfall reductions is not as conclusive as that for increase of air temperature, primarily because rainfall at any given location shows much greater year-to-year variation than air temperature. Moreover, phenomena such as the El Niño Southern Oscillation, which includes both the warming and the cooling phases, 
have a discernible influence on the rainfall of the period that follows it. Yet, even with this analysis, it has been possible to detect important and crucial implications of the observed changes in rainfall. For example, in a majority of locations examined, the length of growing seasons (i.e. maha and yala) for agricultural crops, which is primarily determined by the availability of water, is likely to become shorter.

Although the majority of trends in atmospheric warming and rainfall reductions are common to all seven locations that were examined, there was considerable variation between locations in the respective rates and magnitudes of climate change. There is no doubt that while the global scale processes such as the Enhanced Greenhouse Effect ${ }^{48}$ and the El Niño Southern Oscillation have influenced the climate of Sri Lanka, the global scale impacts have been modified by the local variations in altitude, topography, atmospheric circulation, vegetation etc. Therefore, long-term climatic trends need to be analyzed over a larger number of locations in Sri Lanka to obtain a clearer and a broader picture of the magnitude of climate change in the country. This is an urgent prerequisite in formulating a national action plan to adapt to climate change and mitigate its impacts.

The present analysis used only simple statistical tools such as regression and correlation analysis and analysis of variance in identifying trends of climate change and quantifying their magnitude. More advanced statistical techniques, especially those that separate the inherent variability of climatic data from systematic change over time, may provide a clearer picture of climate change, especially in terms of long-term changes in rainfall. On the other hand, even the simple statistical tools have proved to be adequate in detecting clear and significant trends in air temperature. It must also be noted that the present study is only a description of the long-term trends that can be detected in two key climatic variables. It has not attempted to examine the cause-and-effect relationships or dynamics of variation of these variables. Studies focused on such aspects are urgently needed for a greater understanding of the dynamics of climate change, especially in relation to its spatial and temporal variation in Sri Lanka. It is only with such a mechanistic understanding that prediction of climate change, to any reasonable level of accuracy, becomes possible.

\section{Acknowledgement}

The author gratefully acknowledges the assistance of Prof. V. Nandakumar, Department of Geography, University of Peradeniya in kindly providing the source of a major portion of the meteorological data used in this analysis and Mr. G.H.P. Dharamaratne, Director General, Department of Meteorology who provided the rest of the data at a concessionary rate. Table 1 and Figs. 1 and 2 are from IPCC reports.

\section{References}

1. Crichton M. (2004). State of Fear. Harper Collins, New York.

2. McIntyreS.\&McKitrickR.(2005).Hockeysticks, principal components and spurious significance. Geophysical Research Letters 32: doi:10.1029/2004GL2021750.

3. Intergovernmental Panel on Climate Change (2007a). Climate Change 2007: Synthesis Report. Contribution of Working Groups I, II and III to the Fourth Assessment Report. (Eds. R.K. Pachauri, \& A. Reisinger) pp. 104. IPCC, Geneva, Switzerland,

4. Stern N. (2007). The Economics of Climate Change: The Stern Review. Cambridge University Press, Cambridge, UK.

5. Integovernmental Panel on Climate Change (2001). Climate Change 2001: Synthesis Report. A Contribution of Working Groups I, II, and III to the Third Assessment Report. (Eds. R.T. Watson and the Core Writing Team) pp. 398. Cambridge University Press, Cambridge, UK. and New York, USA.

6. Stanhill G. \& Cohen S. (2001). Global dimming, a review of the evidence for a widespread and significant reduction in global radiation with a discussion of its probable causes and possible agricultural consequences. Agricultural and Forest Meteorology 107: 255-278.

7. Liepert B. (2002). Observed reductions of surface solar radiation at sites in the United States and worldwide from 1961 to 1990. Geophysical Research Letters 29: 1421.

8. Pinker R.T., Zhang B. \& Dutton E.G. (2005). Do satellites detect trends in surface solar radiation? Science 308: $850-854$.

9. Wielicki B.A., Wong T., Loeb N., Minnis P., Priestley K. \& Kandel R. (2005). Changes in Earth's albedo measured by satellite. Science 308: 825 .

10. Wild M., Gilgen H., Roesch A., Ohmura A., Long C.N., Dutton E.G., Forgan B., Kallis A., Russak V. \& Tsvetkov A. (2005). From dimming to brightening: decadal changes in solar radiation at Earth's surface. Science 308: 847-850.

11. Intergovernmental Panel on Climate Change (2000). Emissions Scenarios. (Eds. N. Nakicenovic \& R. Swart) Cambridge University Press, Cambridge, UK.

12. Intergovernmental Panel on Climate Change (2007b). Climate Change 2007: The Physical Science Basis. Contribution of Working Group I to the Fourth Assessment Report (Eds. S. Solomon, D. Qin, M. Manning, Z. Chen, M. Marquis, K.B. Averyt, M. Tignor \& H.L. Miller). pp. 996. Cambridge University Press, Cambridge, UK and New York, USA.

13. Wetherald R.T. \& Manabe S. (2002). Simulation of hydrologic changes associated with global warming. Journal of Geophysical Research 107: 4379. 
14. Huntington T.G. (2006). Evidence for intensification of the global water cycle: review and synthesis. Journal of Hydrology 319: 1-13.

15. Malhi Y. \& Wright J. (2004). Spatial patterns and recent trends in the climate of tropical forest regions. Philosophical Transactions of the Royal Society of London, Series B 359: 311-329.

16. Intergovernmental Panel on Climate Change (2001) Climate Change 2001: The Scientific Basis. Contribution of Working Group I to the Third Assessment. (Eds. J.T. Hougton, Y. Ding, D.J. Griggs, M. Noguer, P.J. van der Linden \& Xiaosu) Cambridge University Press, Cambridge, UK.

17. Burke E.J., Brown S.J. \& Christidis N. (2006). Modelling the recent evoluation of global drought and projections for the $21^{\text {st }}$ century with the Hadley Centre Climate Model. Journal of Hydrometeorology 7: 1113-1125.

18. Meinshausen M. (2006). What does a $2^{\circ} \mathrm{C}$ target mean for greenhouse gas concentrations? a brief analysis based on multi-gas emission pathways and several climate sensitivity uncertainty estimates. In: Avoiding Dangerous Climate Change. (Eds. H.J. Schellnhuber et al.) pp. 265-280. Cambridge University Press, Cambridge, UK.

19. Nakagawa K., Edagawa H., Nandakumar V. \& Aoki M. (1993). Long-term Hydrometeorological Data in Sri Lanka. Project on Hydrological Cycle in Humid Tropical Ecosystems, University of Peradeniya, Peradeniya.

20. Hansen J., Sato M., Ruedy R., Lea D.W. \& Medina-Elizade M. (2006). Global temperature change. Proceedings of the US National Academy of Sciences 103: 14288-14293.

21. Intergovernmental Panel on Climate Change (2001). Climate Change 2001:The Scientific Basis. Contribution of Working Group I to the Third Assessment (Eds. J.T. Hougton, Y. Ding, D.J. Griggs, M. Noguer, P.J. van der Linden \& Xiaosu) Cambridge University Press, Cambridge, UK.

22. Manabe S. \& Wetherald R.T. (1975). The effects of doubling $\mathrm{CO}_{2}$ concentration on the climate of a general circulation model. Journal of Atmospheric Sciences 32: 3-15.

23. Hansen J., Fung I., Lacis A., Rind D., Lebedeff S., Ruedy R., Russell G. \& Stone P. (1988). Global climate changes as forecast by Goddard Institute for space studies threedimensional model. Journal of Geophysical Research 93: 9341-9364.

24. Jones P.D., Wigley T.M.L. \& Wright P.B. (1986). Global temperature variations between 1861 and 1984. Nature 322: 430-434.

25. Wilson C.A. \& Mitchell J.F.B. (1987). A doubled $\mathrm{CO}_{2}$ climate sensitivity experiment with a global climate model including a simple ocean. Journal of Geophysical Research 92: 13315-13343.

26. Rasmusson E.M. \& Wallace J.M. (1983). Meteorological aspects of the El Niño/Southern Oscillation. Science 222: 1195-1202.

27. Chahine M.T. (1992). The hydrological cycle and its influence on climate. Nature 359: 373-380.
28. Jin F.-F. (1996). Tropical ocean-atmosphere interaction, the Pacific Cold Tongue and the El Niño Southern Oscillation. Science 274: 76-78.

29. Changnon S.A. (2000). El Niño, 1997-1998: The Climate Event of the Century. Oxford University Press, New York, USA.

30. Kumar K.K., Rajagopalan B., Hoerling M., Bates G. \& Cane M. (2006). Unravelling the mystery of Indian monsoon failure during El Niño. Science 314: 115-119.

31. Fedorov A.V. \& Philander S.G. (2000). Is El Niño changing? Science 288: 1997-2002.

32. Cane M.A. (2005). The evolution of El Niño, past and future. Earth and Planetary Science Letters 230: 227-240.

33. Collins M. (2005). El Niño or La Niña-like climate change? Climate Dynamics 24: 89-104.

34. Power S. B. \& Smith I.N. (2007). Weakening of the Walker Circulation and apparent dominance of El Niño both reach record levels, but has ENSO really changed? Geophysical Research Letters 34: L18702, doi:10.1029/2007GL030854.

35. Merryfield W.J. (2006). Changes to ENSO under $\mathrm{CO}_{2}$ doubling in a multimodel ensemble. Journal of Climate 19: 4009-4027.

36. Bjerkness J. (1969). Atmospheric teleconnections from the Equatorial Pacific. Monthly Weather Review 97: 163-172.

37. Chen D., Cane M.A., Kaplan A., Zebiak S.E. \& Huang D. (2004). Predictability of El Niño over the past 148 years. Nature 428: 733-736.

38. Fedorov A.V., Harper S.L., Philander S.G., Winter B. \& Wittenberg A. (2003). How predictable is El Niño? Bulletin of the American Meteorological Society 84: 911919.

39. Landsea C.W. \& Knaff J.A. (2000). How much skill was there in forecasting the very strong 1997-98 El Niño? Bulletin of the American Meteorological Society 81: 21072120.

40. Overpeck J.T. \& Cole J.E. (2007). Climate change: lessons from a distant monsoon. Nature 445: 270-271.

41. Anderson D. (2004). Meteorology: testing time for El Niño. Nature 428: 709-711.

42. Zahn R. (2003). Global change: monsoon linkages. Nature 421: 324-325.

43. http://www.cpc.ncep.noaa.gov/products/analysis monitoring/impacts/warm.gif. Accessed on 07 April 2008.

44. http://www.cpc.ncep.noaa.gov/products/analysis monitoring/impacts/cold.gif. Accessed on 07 April 2008.

45. Saji N.H., Goswami B.N., Vinayachandran P.N. \& Yamagata T. (1999). A dipole mode in the tropical Indian Ocean. Nature 401: 360-363.

46. Webster P.J., Moore A.M., Loschnigg J.P. \& Leben R.R. (1999). Coupled ocean-atmosphere dynamics in the Indian Ocean during 1997-98. Nature 401: 356-360.

47. http://www.cpc.ncep.noaa.gov/products/analysis monitoring/ensostuff/ensoyears. shtml. Accessed on 09 April 2008.

48. Houghton J.T. (1997). Global Warming: the Complete Briefing. 2nd Edition. Cambridge University Press, Cambridge, UK. 